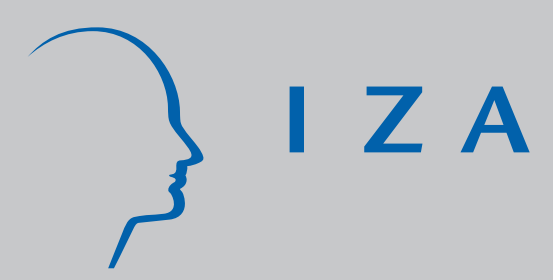

IZA DP No. 5899

HRM Practices and Performance of Family-Run

Workplaces: Evidence from the 2004 WERS

W. S. Siebert

Fei Peng

Yasheng Maimaiti

August 2011

Forschungsinstitut

zur Zukunft der Arbeit

Institute for the Study

of Labor 


\title{
HRM Practices and Performance of Family-Run Workplaces: Evidence from the 2004 WERS
}

\author{
W. S. Siebert \\ University of Birmingham \\ and IZA \\ Fei Peng \\ University of Birmingham \\ Yasheng Maimaiti \\ Xinjiang University of Finance and Economics
}

\author{
Discussion Paper No. 5899 \\ August 2011
}

IZA

P.O. Box 7240

53072 Bonn

Germany

Phone: +49-228-3894-0

Fax: +49-228-3894-180

E-mail: iza@iza.org

\begin{abstract}
Any opinions expressed here are those of the author(s) and not those of IZA. Research published in this series may include views on policy, but the institute itself takes no institutional policy positions.

The Institute for the Study of Labor (IZA) in Bonn is a local and virtual international research center and a place of communication between science, politics and business. IZA is an independent nonprofit organization supported by Deutsche Post Foundation. The center is associated with the University of Bonn and offers a stimulating research environment through its international network, workshops and conferences, data service, project support, research visits and doctoral program. IZA engages in (i) original and internationally competitive research in all fields of labor economics, (ii) development of policy concepts, and (iii) dissemination of research results and concepts to the interested public.
\end{abstract}

IZA Discussion Papers often represent preliminary work and are circulated to encourage discussion. Citation of such a paper should account for its provisional character. A revised version may be available directly from the author. 
IZA Discussion Paper No. 5899

August 2011

\begin{abstract}
HRM Practices and Performance of Family-Run Workplaces: Evidence from the 2004 WERS $^{*}$

This paper analyses HRM practices of family-run workplaces using the 2004 WERS. Familyownership and management within workplaces in the corporate sector is our focus. This family-run group represents nationally about $26 \%$ of workplaces and $14 \%$ of employment. We find that employees in this group have stronger feelings of job security and loyalty, which we relate to family companies' HRM practices such as stronger support for long-term employment - an "inclusivity" linked to long-term orientation. We also find that family-owned and managed workplaces have better financial and quality performance measures than nonfamily, to which family-related HRM practices contribute.
\end{abstract}

JEL Classification: J01, L26, M54

Keywords: HRM practices, family business, loyalty, job security, financial performance

Corresponding author:

W. S. Siebert

Birmingham Business School

University House

Edgbaston

Birmingham B15 2TT

United Kingdom

E-mail: w.s.siebert@bham.ac.uk

\footnotetext{
* We acknowledge the support of the Unquoted Companies Group in carrying out this research. We are also grateful for helpful comments from Alex Bryson, Chris Cracknell, Colin Green, John Heywood, Mary O'Mahony, Xiangdong Wei and Nick Zubanov, and seminar participants at the WPEG Conference, Birmingham Business School, and Lingnan University. Rupert Pearce-Gould at the Centre for Entrepreneurial Learning, Judge Business School also provided good advice on key issues.. Finally, we are grateful to the Data Archive at the University of Essex for supplying the 2004 WERS data. None of these individuals or organisations bears any responsibility for our interpretations of the data.
} 
IZA Discussion Paper No. 5899

August 2011

\section{NON-TECHNICAL SUMMARY}

This paper analyses HRM practices of family-run workplaces using the 2004 Workplace Employment Relations Survey which covers about 2,000 workplaces and 20,000 workers. Family-ownership and management within workplaces in the corporate sector is our focus. This family-run group represents nationally in the UK about $26 \%$ of workplaces and $14 \%$ of employment.

\section{HYPOTHESES}

The paper aims to test whether the hypothesis that family ownership brings longer horizons ("patient capital") since the owners have an incentive to postpone consumption out of a concern for the welfare of the owner's children, grandchildren and other family members. Family ownership is also said to bring a tighter owner-manager link, hence less of a principalagent problem, and better monitoring of management. Therefore "inclusive" management practices may develop.

Against these hypotheses, it is said that families have problems of succession, which might mean less longevity in practice. Also, they have access to a smaller pool of managerial talent - outside managers could be better to reduce this problem.

\section{THE ANALYSIS}

To test the hypotheses we construct four groups of workplaces: family-owned and family managed (FOM), family-owned and non-family managed (FNM), public sector, and nonfamily private. We then compare worker feelings in these four groups, considering particularly worker feelings of loyalty toward their organisation, and their feelings of job security. We find stronger positive worker feelings in the FOM and FNM groups even after extensive controls, e.g. for workplace size, union membership and industry.

The WERS also asks managers to self-assess their workplace's performance relative to their industry. Performance questions are asked regarding financial performance, labour productivity, and quality. The FOM and FNM groups perform significantly better in financial performance and quality, again after extensive controls. Furthermore, we find that worker loyalty and feelings of job security help workplace performance.

\section{CONCLUSIONS}

Inclusive HRM practices can reasonably be linked to family-run businesses' long horizons and management flexibility. Therefore, to answer our hypotheses, family owned management practices confer advantages by improving worker loyalty and job security, and thence firm performance. The policy implication is that long-term family business should be encouraged, e.g. via taxation. Also, a future research direction is the link between Germany's successful mittelstand and family business. 


\section{HRM Practices and Performance of Family-Run Workplaces: Evidence from the 2004 WERS}

"The long-term perspective of family managers is a natural outgrowth of membership in a family system. The extension of horizons acts as an incentive for proprietors to postpone consumption out of a concern for the welfare of the proprietor's children, grandchildren, as well as other family members" (James, 1999, 47).

"Heir managers seem to smooth out employment across the business cycle...providing their workers with long-term implicit insurance contracts." (Sraer and Thesmar, 2007, 711).

\section{Introduction}

Interest in the performance of family companies businesses versus non-family is high. Two recent studies, by Bloom and Van Reenen (2007), and by Bennedsen et al (2007), are critical of the family firm form of governance. At the same time, large family companies appear to be superior in stock market terms (Anderson and Reeb, 2003; Sraer and Thesmar, 2007). Familyowned companies may derive advantages both from better principal-agent alignment, and from extended horizons as stated in James's (1999) quotation above. Our study uses matched employer-worker data from family-owned and non-family workplaces to test for these advantages in the field of labour management.

The family-ownership form of governance might deliver long-term employment stability, but it is not unique in this respect, since public sector organisations do so as well. Generally, in evaluating family ownership (e.g. Harris et al, 2004; Miller et al, 2008) comparisons have been restricted to the private sector. Of course, this restriction is necessary when evaluating market entrepreneurship and company survival, but it need not be applied when considering labour management. From a worker's point of view, jobs in the public and private sectors are simply alternatives. Hence, while a detailed public-private sector comparison is outside our boundaries, including the public sector in the comparisons will provide a useful extra dimension.

Within the private sector, non-family-owned companies, for their part, are admittedly heterogeneous. On the one hand, we have the large listed companies without family control, which can be termed "manager controlled" (following Werner et al, 2005). Here, there is the classic division of ownership from control, giving a principal-agent split that can permit managers to pay themselves too much, and grow too much. Then, there are all the other company types, which we term "founder-run" - sole proprietors, partnerships, and private limited companies. Some of these might develop a trans-generational strategy and become family companies, but they might not. For example, it may be argued (Villalonga and Amit, 2006,389 ) that founder-run firms such as Microsoft "are not family firms in any meaningful sense of the term" since the founder cashes in rather than transfers within the family. Hence, either because of manager control, or because of uncertainty over transfer within the family, the private sector non-family companies do not necessarily have the trans-generational strategy and long horizons. Consequently we lump them together in what follows.

The question we ask is whether the family-owned type develops a distinctive employment relations which helps business performance. In particular, we might expect family-owned companies' tighter owner-manager link and longer horizons to allow greater employment security (as in Sraer and Thesmar's quotation above), and encourage more worker loyalty. Of course, family-owned companies may have quite short lives, and they certainly have management succession problems. For this reason, below we will distinguish between family-owned companies which are family managed, and those which are non-family managed, that is, where outside managers are brought in to widen the management pool and 
reduce succession problems. The 2004 WERS is a nationally representative dataset of more than 2,000 workplaces, around 500 being family-owned. Also, within these workplaces around 20,000 workers are surveyed, and the WERS therefore forms a good basis for our comparative inquiry.

\section{The literature}

We consider first the issue of defining family-owned companies. Then we turn to findings on advantages and disadvantages of these companies, particularly in the area of employee relations.

Defining family-owned companies. It is difficult to define "familyness", and there is a large literature (for a survey see Klein 2005). Westhead and Cowling (1998) consider a spectrum of conditions, ranging from a simple family majority ownership requirement through multiple conditions including majority ownership, family management, and inter-generational transition. Of course, the more restrictive the conditions, the smaller the family-owned category become. For example, in the Annual Small Business Survey $(2005,235)$, while $70 \%$ of the small businesses are family-owned assuming majority ownership by one family, this figure drops to around 35\% if we include only businesses which bring in the second or later generations (Westhead and Cowling's (1998) dataset exhibits a similar fall).

The importance of inter-generational transfers for the family-owned company is that they promote long horizons. The link with long horizons is shown rigorously in James's (1999) model of transfers between a proprietor and his/her children (see also Chami, 1999). James shows that the proprietor's utility from his/her children's utility increases the proprietor's investment in the firm, so long as the child receives utility when the firm's returns increase. This proposition has the corollary that while most companies begin as founder-run companies, it is only when future generations are considered that behaviour alters to consider a longer run than the market would require. This model abstracts from real difficulties (Schultze et al, 2003) of children trying to manipulate parents, for example for added compensation or an increased share of the estate - and also that parental rewards are uncertain. This said, the underlying theme is that family-owned companies should invest in projects which bring a lower rate of return than the market requires, because these companies have a longer horizon than the market, their capital is "patient".

Thus, the salience of the restrictive family-owned company definition based on the inter-generational transfer is widely argued. For example, Klein et al $(2005,325)$ state that "an enterprise can only be viewed as a family business when a transfer to the next generation is intended", and many others make a similar point (see Arregle et al, 2007; Chua et al, 2004; Habbershon et al, 2003; Kotey and Folker, 2007; Poutziouris, 2006). Sraer and Thesmar $(2007,711)$ even speak of "dynastic management and ownership". The consequence of the restrictive definition is that it places the large group of founder-run companies outside the core family-owned category.

Differentiating between companies on the basis of their trans-generational strategy is important, but might not be achievable empirically. To some extent, strategies represent aims, and we can only observe actions. In practice, the simple criterion of majority ownership by one family (GEEF, 2009) is often taken, irrespective of whether transfer to later generations is intended. In fact, Westhead and Howorth (2006) found that only half the multi-generation family-owned companies in their sample had as a "prime objective" passing the business onto the next generation. Consequently, even with good data on actual transfers, we will be missing strategy. In practice, therefore, our "family" and "non-family" division does not fully 
reflect the division in transgenerational strategy ${ }^{1}$, and so our comparisons are weakened. Hopefully, the family-managed category still captures something of the trans-generational strategy.

Advantages of family ownership. In the first place, with the generations linked in the same company, business training should be more effective than in the "school of hard knocks" faced by entrepreneurs starting out without a family backing. Such training should help develop successful entrepreneurship. Bjuggren and Sund (2005) describe the younger generation's unique position to pick up "family idiosyncratic knowledge". Such knowledge is meant to be based on intensive discussions of the firm's problems within the family circle: "transfer of knowledge may start at the dining table, subtly and imperceptibly" (LeBreton et al, 2004, 309). These discussions will extend to knowledge of the network of suppliers, customers and finance sources - all of whom in turn will get to know the family members and learn to trust them.

Admittedly, the notion of family idiosyncratic knowledge is difficult to test. However, Dunn and Holz-Eakin (2000) show that a person is much more likely to be self-employed if his father is self-employed than if his father is not self-employed (see also Colombier and Masclet 2008). They believe that this result suggests that parents pass on entrepreneurial and management skills to their offspring, which can be taken as forms of idiosyncratic knowledge. (For the UK, 29\% of sons with self-employed fathers are self-employed, but the figure is much lower, 15\%, for sons of employed fathers - Taylor, 1996, 266). Also suggestive is Michelacci and Silva's (2008) research on why employees are less likely to work in the region in which they were born than are business owners, because it shows the importance to business of personal networks which are built up by staying put and using family connections. In a related vein, Fairlie and Robb (2007) show that small business success is linked with prior work experience in a family-owned company which they interpret as a method of acquiring business skills.

There is also the fact that ownership is less divorced from control in the family-owned company, so there is less of an agency problem in relations between owners and managers. Thus, even if the family-owned company is run by a non-family outside manager, monitoring will be more successful than in the widely owned listed company - or in the public sector. Consequently, we would expect (Sciascia and Mazzola, 2008; Werner et al, 2005) CEOs to be better monitored in family-owned companies. They will be paid less, and will have their pay better linked to performance rather than to company size. Importantly, Werner et al (2005, 379 ) argue that such more careful monitoring will "cascade" through the organisation (see also Carrasco-Hernandez and Sanchez-Martin, 2007) making lower-level pay more sensitive to performance as well. This argument can also be applied in reverse to the public sector, where monitoring should be less careful and pay given productivity higher (Postel-Vinay and Turon, 2007) because of political discretion.

While it is possible that family-owned companies' lesser principal-agent problems allow them to achieve lower unit labour costs, this proposition is difficult to test because comparable measures of worker product are not available. In practice, we hold measured worker skills constant, but have to omit the important worker effort variable. Sraer and Thesmar $(2007,728)$ find some evidence in their sample that family-owned companies pay lower wages for given skill (Bassanini et al, 2010 make a similar finding for a French sample including also non-listed firms), and propose that the reason is that family-owned companies can credibly commit to long-term employment. They "smooth out" industry shocks and

\footnotetext{
${ }^{1}$ In future work to capture the intergenerational aspect with these data it would be worth distinguishing the older family-run workplaces which are more likely to be intergenerational. We are grateful to Colin Green for this point.
} 
workers therefore accept lower wages. Nevertheless, Akerlof and Kranton $(2005,15)$ note that workers who identify with their organisation (as in family-owned business) are likely to work harder, and exert more "effort" - for which they will receive extra pay. Since our data source does not have a good measure of effort we cannot pursue the wage investigation in detail, though we present some results.

It is argued that family-owned companies are better able to build trust and loyalty among workers. According to Arregle et al $(2007,76)$, "By modelling trust, the family provides the foundation of moral behaviour on which its guidelines for cooperation and coordination as well as principles of reciprocity and exchange are developed". Such trust depends on company identity and stability (Leana and Van Buren, 1999), and builds the foundation for social capital within the firm, that is, "organizational social capital". The concept of organizational social capital refers to relationships which limit opportunistic behaviour within an organization - these relationships become a resource which increases productivity. This concept can be related to "stewardship" (see Miller et al. 2008) which links the continuity of the family-owned company business to the development of a "community" culture.

A similar view (Mueller and Phillipon, 2006) is that family-owned companies develop "welfare paternalism" whereby the controlling family takes the workers' welfare to be a personal responsibility. Such paternalism gains credence from the fact (Sraer and Thesmar, 2007, 733) that family-owned company CEOs have lower turnover than non-family.

Disadvantages. A trans-generational strategy may impose some constraints, particularly in terms of succession planning, and access to management talent. Taking the issue of succession first, this problem might be considered the Achilles heel of family governance, and it is one of the main topics (Chua et al, 2003) in this literature. Inadequate or no succession planning is the most cited reason (Le Breton et al, 2004; Demassis et al, 2008). The founder is unable to let go perhaps because, in Barnes and Hershon's $(1976,108)$ classic phrase, "giving up the company is like signing his own death warrant". Of course, a further obstacle is the inheritance tax difficulties associated with succession.

Because of succession problems the life of a family business might be quite short in practice. Hence Lambrecht $(2005,267)$ states that "the average lifespan of a family business is 24 years, which is the average number of years that the founder remains at the helm". Le Breton-Miller at al $(2004,306)$ state that only one-third of family-owned businesses survive to the second generation, and $10-15 \%$ to the third. Still, it is worth noting that it is the first succession which is most problematic (Bjuggren and Sund, 2001), and survivability improves for subsequent successions perhaps because of experience gained. Overall, on the basis of this discussion, we would expect family-owned companies to have especially high chances of failing when the first generation retires, that is, for companies 15 to 20 years old. Thus, there is a case here for considering survival of companies older than 15-20 years old separately from the younger group.

The other major potential problem of the family-owned company is the smaller pool of managerial talent. Thus, some research (e.g., Barth et al 2004, Bennedsen et al 2007, Bloom and Van Reenen 2007) points to family-owned firms being less productive when there is family management. A possible explanation for this finding is that family managers are drawn from a smaller pool, and hence are less skilled than outside managers. Certainly, family managers have (Bennedsen 2004; Reid and Adams 2003) less schooling/college, and less previous board experience. On the other hand, research on the passing on of entrepreneurial and managerial skills in family-owned companies noted above (Dunn and Holz-Eakin, 2000; Colombier and Masclet 2008) suggests that it is hardly surprising that family managers have 
less formal training, since they pick up skills informally in the their company. Moreover, Anderson and Reeb's $(2003,1317)$ results for US listed companies actually find that family CEOs are helpful for productivity, a finding replicated in Sraer and Thesmar's $(2007,711)$ French sample. Therefore, it is important to distinguish family-owned and managed workplaces from family-owned and non-family (outside) managed, which the WERS dataset allows us to do.

\section{Hypotheses}

From the discussion above, we take four basic types of business governance (see Table 1): - family-owned and family managed workplaces (FOM), which is our core "family-run" group;

- family owned and non-family managed workplaces (FNM);

- all other private sector workplaces;

- public sector workplaces, which include public administration and most of health and education.

We then bring forward the following hypotheses to test the contrast between the four types.

Company stability. A basic hypothesis relevant for employment relations is that family-owned companies, both FOM and FNM types, offer more stability than non-family. From stability should flow the consequences of deeper trust relationships in family businesses, and hence better industrial relations (Mueller and Phillipon, 2006), and more loyalty (Carlson et al, 2006). Lower labour turnover might also result - though it must be remembered that efficient management (Siebert and Zubanov 2009) might require quite high turnover.

There are several indicators of organisational stability, the most direct being workers' own feeling of job security, about which the WERS asks several questions. Worker tenure is also relevant for investigating labour turnover issues. A further direct measure is how long family-owned companies survive (see e.g., Perez et al, 2004), which we will also consider using data on company closures. By distinguishing between FOM and FNM family types we can test whether the core FOM type is more or less stable.

Company performance. Company performance is fundamental, and as noted above, there is a literature on the relative performance of family-owned companies, with positive results though suggesting that the FNM type outperforms the FOMs. We will make a further contribution, using the WERS performance measures based on manager self-assessed relative financial, productivity and product quality. At the same time, it must be remembered that labour management can only be expected to explain a part, perhaps quite small, of performance. Our data does not permit us to test for the role of other family-management dimensions including capital, marketing and customer relations (see Miller et al 2008). This said, at least we can hope to pin down the labour management contribution, and test how the FOM type performs.

Company performance also links with worker loyalty and security (see Brown et al, 2010), since more loyal/secure workers should be more diligent and care about quality. We will test for the positive links between loyalty/security and company performance (see below). If family-owned companies do indeed generate more loyalty/security, as discussed next, we would expect an advantage from this quarter for family-owned companies.

Worker loyalty and security. The supposed deeper trust relations in family-owned companies, combined with organizational stability should generate worker loyalty and felt job security. There are also indications that family-owned companies are managed in a characteristically different way, with less formal procedures (Harris et al, 2004; Kotey and Folker 2007, 219), and "more flexibility and inclusivity" (Miller et al., 2008, 56). Such flexibility is perhaps to be 
expected given better entrepreneurial training in the more inclusive FOM type. Greater informality, flexibility and inclusivity should cause greater worker loyalty/security.

Alternatively, if family-owned companies are conservative and nepotistic, as in Miller et al's (2008) "stagnation perspective", worker feelings of loyalty/security should be lower.

The proposition of greater loyalty/security is testable given measures of worker feelings, which are available in the worker questionnaire section of the WERS (see below). We can also test for whether family firms' workers have lower turnover, ceteris paribus, a dimension which also relates to loyalty and trust relations - though, as noted above, the "right" amount of labour turnover is hard to determine, and union activity, for example, can cause turnover to be "too low". In particular, if family firms face lower firing costs (Daniel and Siebert, 2005), they will be more able to hire "outsiders" without a track record. Such outsiders, e.g., the young and inexperienced, will naturally have higher turnover. For all these tests we carry along the distinction between FOM and FNM types.

A final possibility raised in the literature is that family-owned companies offer extra training (Miller et al, 2008). Training itself might be a way of reinforcing worker loyalty. However, this proposition is difficult to test satisfactorily given the WERS data, which refer only to formal training which bypass informal methods "sitting by nelly". However, we present exploratory results for formal training since training is important.

The model. In sum, we have the following model. First, we suppose that management HRM practices $(\mathrm{P})$ are determined by the four governance types (vector $\mathbf{t}$ containing types 1 to 3 relative to a reference type 4 which we take as non-family private). For example, if FOM companies have greater stability and long-term outlook, these companies should lay more emphasis on long-term employment practices. There will be several of these equations, one for each "practice" - we take six, as discussed below. Hence, we write in matrix form:

$$
\mathbf{p}=\mathbf{P t}+\mathbf{K} \mathbf{x}_{\mathrm{P}}
$$

where $\mathbf{p}$ is our $6 \times 1$ column vector of practices, $\mathbf{t}$ the vector of types, $\mathbf{P}$ is the $6 \times 3$ matrix of coefficients giving the effect of $\mathbf{t}$ on $\mathbf{p}$, and $\mathbf{x}_{\mathrm{P}}$ is the vector of other determinants of practices such as, for example, firm size and industry, with a matrix of coefficients, $\mathbf{K}$.

In the set of $\mathbf{p}$ management HRM practice variables, we included six practices (see Appendix Table 1) as follows:

- given that our emphasis aim is to test for family-run long-term horizons we formed a variable for whether management led workers to expect long-term employment ("inclusivity");

- whether the workplace had a no-redundancy policy, which can be taken as a more formal, somewhat contrasting (because reducing management flexibility) variant of the first practice;

- an index of "innovative" HRM practices, to pick up several dimensions of what might be thought of as good management. This variable follows Harris et al (2004), but also takes in dimensions of Bloom and Reenen's (2007) good management concept, including performance appraisal, discretion in work, and incentive pay. In fact, as we will see, innovative practices might in fact stress workers, reducing job security, but they are certainly important;

- a high (formal) training practices indicator, since as noted above, training could be another aspect of "good" management, possibly encouraging loyalty.

- a measure of the workplace's relative wage (relative to the average for its occupational composition and industry), which is relevant since workplaces giving a high relative wage (Akerlof and Kranton, 2005) may generate more loyalty, but less security. A high relative wage might also indicate a type of efficiency wage policy; 
- finally, the workplace's average working hours, since high hours may indicate effort and loyalty.

Admittedly, there are many other practices, for example control of unionism (prevalent in the FOM type). While these other practices are not our focus, we control for many of them, and will be able to pick up their effects.

Second, we suppose that practices and governance type determine worker feelings (f) of loyalty and job security. Hence, again in matrix form, we write:

$$
\mathbf{f}=\mathbf{F t}+\mathbf{G p}+\mathbf{M} \mathbf{x}_{\mathrm{F}}
$$

where $\mathbf{f}$ is our column vector $(2 \times 1)$ of feelings, $\mathbf{F}$ is the matrix of coefficients giving the direct effect of $\mathbf{t}$ on $\mathbf{p}, \mathbf{G}$ is the matrix of coefficients giving the effects of $\mathbf{p}$ on $\mathbf{f}$, and $\mathbf{x}_{\mathrm{F}}$ is the vector of other determinants of feelings including not only firm characteristics such as size, but also worker characteristics such as education and age, with a matrix of coefficients, $\mathbf{M}$. Ideally, if we include all relevant policies measured correctly, the effect of $\mathbf{t}$ will disappear in this equation, ie $\mathbf{F}$ will be small. However, in practice $\mathbf{t}$ is still likely to retain a role, if only because our list of other determinants, $\mathbf{x}_{\mathrm{F}}$ is incomplete. The role of $\mathbf{t}$ then becomes something of a black box.

Third, type, feelings and policies will in turn feed through to company performance y: $\mathrm{y}=\mathbf{A t}+\mathbf{B f}+\mathbf{C p}+\mathbf{D z}$

where $\mathbf{A}$ is the transposed vector $(1 \times 3)$ of coefficients giving the direct effect of $\mathbf{t}$ on $\mathbf{y}, \mathbf{B}$ is the vector of coefficients giving the effects of $\mathbf{f}$ on $\mathbf{y}, \mathbf{C}$ is the vector of coefficients giving the effects of $\mathbf{p}$ on $\mathbf{y}$, and $\mathbf{z}$ is the vector of other determinants of performance, with associated coefficient vector $\mathbf{D}$. Ideally, $\mathbf{z}$ should include measures of marketing practices, customer relations and financial management, few of which are directly available in the WERS (though we control for many associated factors such as industry), so these factors will tend to load onto A. In practice, we will have three performance equations, reflecting the three WERS measures of performance (financial, productivity and quality). In these equations as well, governance type in practice $\mathbf{t}$ is still likely to retain a direct role (A will be large), if only because our list of other determinants, $\mathbf{z}$ is incomplete.

The full effect of governance type on performance can be written in terms of "direct" effects through equation (3) and "indirect" effects through equations (1) and $(2)^{2}$. In other words, the FOM governance variable may show a positive direct effect on, for example, financial performance, holding constant worker feelings and HRM practices. At the same time, FOM governance also affects worker feelings, for example raising feelings of job security, which in turn improves financial performance through its coefficient in equation (3). This effect can be thought of as indirect because it is operating at one remove, via worker feelings. Similarly, FOM governance can operate indirectly via one of the HRM practices, for example the practice of leading employees to expect job security which in turn raises job security feelings and improves financial performance. Here we have an FOM effect on financial performance working at two removes, via HRM practices which affect feelings. Below (Table 5), we aim to trace both the direct and indirect effects.

Our basic hypothesis therefore is that the stability and long-term outlook of familyowned companies manifests itself in different labour management practices. These practices then generate beneficial feelings of greater loyalty and job security among workers (as well as having effects in other areas such as customer relations which we cannot measure). Finally, practices, worker feelings, and family governance type are beneficial for performance.

\footnotetext{
${ }^{2}$ Substituting from equations (1) to (3) we derive y $=(\mathbf{A}+\mathbf{B F}) \mathbf{t}+(\mathbf{B G}+\mathbf{C}) \mathbf{p}+\mathbf{D z}$. Differentiating with respect to $\mathbf{t}$ gives $\mathrm{dy} / \mathrm{d} \mathbf{t}=\mathbf{A}+\mathbf{B F}+(\mathbf{B G}+\mathbf{C}) \partial \mathbf{p} / \partial \mathbf{t}$. Here $\mathbf{A}$ gives the "direct" effect of type on performance, holding $\mathbf{f}, \mathbf{p}$ and $\mathbf{z}$ constant. The $\mathbf{B F}$ term then shows "indirect" effects of type through $\mathbf{f}$, and the final bracketed term the effect of type through $\mathbf{p}$.
} 


\section{The Data}

The data are drawn from the WERS 2004 Cross-Section Survey (see Department of Trade and Industry, 2005). We briefly also consider the 1998-2004 WERS Panel Survey for workplace survival analysis.

This WERS provides linked employee-employer data, and is nationally representative (Kersley et al, 2006) of all workplaces in Great Britain employing more than 5, excluding agriculture and mining. The final sample is 2,295 workplaces, and about 23,000 employees. The survey is comprehensive, the manager assisting in filling in the questionnaire being the "the senior manager dealing with personnel, staff or employment relations", who was interviewed for about 2 hours. Furthermore, at each workplace a questionnaire is administered to a random sample of 25 employees (or all employees in workplaces with 5-24 employees). This process was successful in about $60 \%$ of workplaces (Chaplin et al, 2005, tables 5.16 and 5.17). In addition to questions on earnings and personal background, the worker questionnaire probes worker feelings of loyalty and job security which are of particular interest to us.

Because the data are provided at two levels, care is needed in weighting and interpretation. At the workplace level, the survey follows a stratified random sample design (Chaplin et al, 2005, 104) which oversamples larger workplaces. This oversampling is counteracted using workplace weights supplied with the dataset to give national representativeness. At the same time, at the worker level a further bias is caused by the fact that workers in larger workplaces are under-represented because of the 25 worker maximum. For analysis of worker variables, such as worker feelings of loyalty, it is then necessary to apply worker weights which both counteract oversampling of large workplaces, and undersampling of workers within large workplaces. In the analyses below we will make clear the weights that we use for different aspects of the analysis.

From this dataset we construct two family ownership variables. The first is based on whether the workplace is family-owned, defined as a single individual or family owning as least $50 \%$ of the company. The second indicates whether, in addition, the workplace is actively managed by one of the family. This addition we take as implying more "familyness" and gives us our FOM type. We then take the remainder of family-owned workplaces as having non-family (outside) management, and forming the FNM type. (Note that some of the FNM workplaces could have a family member managing at the HQ level, in a large organisation). Admittedly, neither of these definitions corresponds precisely to the concept of family ownership as a "strategy" of family control across the generations. However, as we have seen, definitions based on percentage family ownership are conventional. Moreover, as we now describe, the definition of family-owned excludes "founder-run" companies which helps focus on "core" family-ownership.

On the issue of excluding founder-run companies, in the 2004 WERS the familyownership questions were only asked of corporate bodies such as public and private limited companies. In other words, the family ownership status of unincorporated business types, the most numerous of which are partnerships and sole proprietorships, remains unknown. (Further types, such as cooperatives, mutuals, and charities were not asked either, but would necessarily be non-family.) The simplest approach is then to assume partnerships and sole proprietorships are non-family in strategy. This assumption can be justified on the grounds that, even if some family ownership is involved, it is of the "founder" nature and therefore has not developed into a family-ownership strategy in accordance with our discussion above of the family-ownership concept.

As a subsidiary dataset, we also use the 1998-2004 WERS Panel Survey for analysis of business survival. This inquiry (Chaplin et al, 2005, section 2.4) followed a sample of the 
1998 Survey's workplaces and is able to give us information on whether the workplace closed down by 2004. However, the family ownership variables in the Panel Survey are confusingly different from those already described for the 2004 WERS, because the 1998 Survey did not ask the family-ownership questions of public limited companies. Since public limited companies have a considerable family-ownership proportion, they then have to be excluded completely from the survival analysis (see also Harris et al, 2004), which limits the extent to which we can generalise our findings. (By contrast, it will be remembered that our 2004 analysis can include public limited companies.) Nevertheless, analysis of the panel gives some insights, and can be combined with the WERS 2004 cross-section information on how long a workplace has been in existence, which also gives a view on survival.

\section{Family vs. Non-family: Similarities and Differences}

Family business numbers and sizes. Let us start with what the sample implies about the national UK importance of core family-ownership. Table 1a gives weighted numbers of workers and workplaces in the sample. Blowing these up to national level should give nationally representative proportions. Starting with workplaces, the second row gives 601 FOM workplaces, $26 \%$ of the total of 2295 workplaces. This $26 \%$ figure corresponds to the national proportion of family-owned and managed workplaces employing more than 5 workers. Adding in the $221 \mathrm{FNM}$ workplaces brings the family-owned proportion up to $36 \%$ of the national total (and over $40 \%$ of the private sector) - the rest being "founder" or simply public or private sector non-family. Thus, family-owned workplaces, as we have defined them, form a substantial minority of the nation's workplaces.

However, family-owned workplaces are not so important in worker terms, since most workers are employed in large enterprises (see the memo item in the last row), while family owned companies tend to be small. The worker picture can be assessed from the last row of Table 1a. Here we see that 3,240 workers are employed in FOM workplaces, which is $14 \%$ of the total $(23,012)$. Adding in the 1,719 employed in FNM workplaces gives $21 \%$. The implication is that only $21 \%$ of the nation's workers (in workplaces employing more than 5) work in family-owned workplaces. Thus, the worker viewpoint is different from that of the workplace, and gives less importance to the family. Which viewpoint we take depends upon the purpose at hand. For example, considering worker feeling of loyalty, it is natural to take the worker viewpoint. On the other hand, our main purpose in this paper is to explore the consequences of different forms of ownership, and then it is natural to take the workplace (ownership) viewpoint.

As a further point on structure, it is worth looking at the size of the organisation, rather than the workplace, given that approximate organisation size estimates are available from the workplace's manager reports. (Table $1 \mathrm{~b}$ shows that while $69 \%$ of FOM workplaces are single, not belonging to another body, the corresponding figure for the private sector non-family group is only $27 \%$, implying that here the organisation is generally much larger than the workplace.) We see that the average FOM organization employs 3-400 workers, placing it in the medium-sized group, while FNM organisations are in the large-sized group, and private sector non-family are larger still. Thus, our core family type is smaller on average than the other types.

HRM practices. Let us now consider the six HRM areas discussed above. We start Table $1 \mathrm{~b}$ with whether management encourages a feeling of belonging (Miller et al's (2008) "inclusion") by giving employees the expectation of long-term employment. As we see, the percentage of managers of both FOM and FNM workplaces that strongly encourages such an expectation is higher ( 31 to $33 \%$ ) than for the other two types ( 24 to $25 \%$ ). Interestingly, we see that the second practice we distinguish, the no-redundancy guarantee, shows a converse pattern, being highest in the public sector, and lowest for the FOM type. The two methods of 
promoting job security have different roots (no-redundancy guarantees being associated with union power), and clearly are worth distinguishing.

As regards our third area, "innovative" HRM practices, we see that there are fewest (4 out of 13) in the FOM category. These workplaces also have lower showing in our fourth area, formal training, with only $21 \%$ f the workforce receiving more than 2 days training in the previous year, much less than other groups. Fewer innovative HRM practices and less training might be thought simply to reflect the smaller size particularly of FOM businesses, or technological differences - perhaps more low-tech industries and less educated workforces. In fact, these explanations are insufficient, since both FOM and FNM type workplaces tend to have fewer innovative practices and less training even after many controls (see Appendix Table 1). Family-run workplaces really are run more informally (see e.g., Kotey and Folker, 2007), as already observed in the literature.

Our fifth area is relative workplace earnings. As a summary measure, roughly holding other things constant, we express workplace average wage relative to the average that would be expected in the workplace's industry and given its occupational composition. We see that the FOM and FNM types have somewhat lower workplace relative wage (97 and $93 \%$ of the expected average), compared to the private non-family (100\%) and public sector $(102 \%)$ types. However, as already noted, even when full controls are used (Appendix Table 1) it is difficult to be sure we are comparing like with like.

Finally, we consider working hours, since long hours may indicate both effort and loyalty (the extra mile).We see that working hours are much longer in the FOM type (38.4) than the other types. This pattern remains (Appendix) after full controls. Thus, a defining characteristic of FOM governance is longer working hours practices, presumably implying more intense work.. We discuss below the implications of long hours for worker feelings and company performance.

Worker loyalty and job security. We formed indexes for worker feelings of loyalty and job security based on WERS questions as shown in the Notes to the table. The indexes show that the average worker in a FOM workplace scores 2.97 out of 4 for job security, and 3.1 out of 4 for business loyalty. Figure 1 shows the distribution of scores, contrasting FOM with nonfamily, private. The proportion of workers in the top group is nearly $30 \%$ for FOM workplaces compared to around $20 \%$ for non-family. Of course, this difference could simply reflect the well-known link between job satisfaction and small firm size, and so requires proper control (Tables $2 \mathrm{a}$ and $\mathrm{b}$ ). Still, we see already a plausible link between the FOM business's long term horizons and increased worker loyalty and job security.

The public sector results appear paradoxical with low worker-felt job security despite the fact that public sector workplaces have little possibility of closure (see the workplace age row in Table $1 \mathrm{~b}$ ), and worker tenure is longer ( 8.9 years compared to around 6 for other groups - see also Table $3 \mathrm{~b}$ below). The implication is that possibilities of workplace closure are not as important as might be thought for worker-felt job security, and other policies linked with family long horizons and "inclusion" have a role.

It is worth considering briefly at this point the other main worker characteristics. We see that both family-run types have less educated workforces. In part, this difference will reflect technology, but perhaps it also reflects more flexibility, as noted already. In other words, giving unskilled workers "a chance" inevitably means tenure will be lower. The public sector group is the outlier here, with much longer tenure, and this difference remains after extensive controls as we will see. 
Workplace characteristics. Turning to the workplace variables in Table 1b, we begin with performance measures. These are subjective measures, which all depend upon manager judgements. An attempt is made in the 2004 WERS to collect hard financial data, but these data (see Brown et al, 2011) have many missing values, so we are left with the manager judgements, which nevertheless have been extensively (see e.g. Brown et al 2011). As regards relative financial performance, we see that the FOM category performs worse (averaging $2.47)$ than the non-family category (2.53) which is similar to the FNM category (2.58). While there is not much of a pattern here, it is necessary to add controls which we will find make a difference.

As regards relative productivity, and particularly quality, managers in FOM workplaces appear to perform better than the rest. Here we see signs that the family-owned form of governance delivers efficiency, at least within the quality context. The hypothesis advanced above is that extra loyalty and feelings of job security generated by familyownership also helps generate performance, which we will test below.

The lower panels of Table $1 \mathrm{~b}$ list our controls. As already noted, we see that publicly listed companies form a small proportion $(6 \%)$ of the FOM category, but a much higher proportion both of FNMs (29\%) and the private sector non-family (32\%). Another structural difference is the small impact of foreign ownership (1\%) among the FOM category, and the large impact (19\%) among the FNMs. This difference goes along with the high proportion $(69 \%)$ of single stand-alone workplaces among the FOMs, compared with $19 \%$ in FNMs.

As regards industry composition, we see that the FOM group is much stronger in manufacturing ( $21 \%$ of the category's workplaces) and construction (14\%) than the other three groups. The FNM category is strongest in retailing (53\%). The private sector non-family category is strongest in financial $(10 \%)$ and other business services $(19 \%)$. Finally, the public sector of course contains all the public administration, and most of the education and health services workplaces. While the focus of this study is not on why some businesses develop a family-ownership strategy, these differences in industry composition point to some answers. Thus, manufacturing and construction have a smaller minimum efficient size, and might be said also to benefit from the family management close customer care (Miller et al, 2008) and so fall naturally into the FOM category. On the other hand, financial services such as banking can more easily float on the stock market and so lose their family connections. Again, it might be argued that large retail enterprises stretching across the country (for example, Sainsbury's) need to develop outside management even if they retain their family roots, and so tend to evolve into the FNM category.

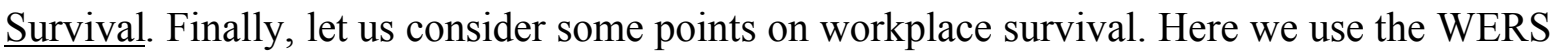
1998-2004 panel, remembering that the sample is smaller than that of the WERS 2004 since public limited companies were not asked the family-ownership questions in 1998. Overall, using unweighted figures for simplicity, of the 666 workplaces in the sample in 1998, 97 closed between 1998 and 2004. The proportions closing were 15\% for FOM, 22\% for FNM, and $13 \%$ for non-family which suggests that the categories are quite similar, and does not support the hypothesis of family-owned longevity. At the same time, there is no indication that family-owned companies have a much shorter lifespan as has sometimes (e.g., Lambrecht, 2005) been argued.

Workplace age is another way of considering survival. Admittedly, the current age of a workplace (see Table 1b) does not tell us how long it will eventually survive, but it is informative nevertheless. Figure 2's histograms give the patterns in the data. We see that the WERS sample has some very long-lived businesses. In fact, while the graphs in Figure 2 are truncated at 200 years, several old schools and pubs record ages of over 400 years. Still, as 
already noted, the average age for family-owned workplaces is somewhat lower than that for non-family, indicating that family ownership means lower survival probability, at least in the absence of controls.

The recommended method (e.g., Cleves et al, 2004) for analysing survival is via a Kaplan-Meier survival function which operates on actual observed workplace closures. This function shows the probability of survival beyond a given age as the product of the probability of surviving for each of the intervening years. We see from Figure 3 that the survival experience is quite similar until after approximately age 70, when the non-family function becomes superior. However, workplaces for all three groups have a high probability of survival: $95 \%$ of all groups survive longer than 7 years, and $75 \%$ last more than 40 years. Therefore, our conclusion of similarity remains. (In a multivariate hazard analysis, available separately from the authors, this conclusion is upheld.) Interestingly, the indications of somewhat shorter lives for family-run businesses need not be incompatible with high worker loyalty and feelings of job security, as we have already seen in outline above.

\section{Results}

In this section, we start with the group of worker variables, first, worker feelings of loyalty, and then job security. These estimations correspond to equation (2) in the model above. We start with these equations both because they are interesting in themselves, and because they show consequences of the various management practices that underlie the model's basic equations (1). Subsequently we will discuss these equations. Finally, we will take up issues of business performance, that is, equation (3).

Worker feelings of loyalty and job security. Brown et al (2011) have already analysed various dimensions of worker loyalty using the WERS. Their procedures therefore form a pattern for us to follow, which we adopt also for the job security dimensions. In particular, since the loyalty and job security indexes have 5 ordered categories, an ordered probit specification is appropriate. Thus, for the loyalty index we have a probit version of equation (2) above:

$$
\text { loyalty }^{*}{ }_{\mathrm{ij}}=\alpha+\mathbf{F t}_{\mathrm{j}}+\mathbf{G}_{\mathrm{j}}+\mathbf{M x}_{\mathrm{ij}}+\mathrm{e}_{\mathrm{ij}}
$$

where loyalty* ${ }_{\mathrm{ij}}$ is a latent variable for the unobserved feelings of loyalty to the $\mathrm{j}$-th workplace experienced by the $\mathrm{i}$-th worker, which we replace with the observed 5-category index. $\mathbf{t}_{\mathrm{j}}$ is the vector of workplace' governance types, $\mathbf{p}_{\mathrm{j}}$ its vector of management practices, and $\mathbf{x}_{\mathrm{ij}}$ is the vector of controls expected to influence loyalty ${ }_{\mathrm{ij}}$, and $\mathrm{e}_{\mathrm{ij}}$ is the error term.

Similar reasoning gives a generalised ordered probit for job security: job security ${ }_{\mathrm{ij}}=\alpha+\mathbf{F t}_{\mathrm{j}}+\mathbf{G}_{\mathrm{j}}+\mathbf{M x}_{\mathrm{ij}}+\mathrm{e}_{\mathrm{ij}}$ where job security ${ }_{\mathrm{ij}}$ is a latent variable for the unobserved feelings of job security within the $\mathrm{j}$-th workplace experienced by the $\mathrm{i}$-th worker, which we again replace with the observed 5category job security index.

The ordered probit technique brings difficulties (Greene, 2004, 739) in that the coefficients $\mathbf{F}$ and $\mathbf{G}$ affect all five categories of the dependent variable differently, so it is not clear what the coefficients mean apart from summarising a positive/negative direction of influence. However, marginal effects can be calculated for each of these categories, and these provide a clearer picture. At the same time, coefficients from the full equations are useful in summarising the effects of many variables, so we present the full equations as well. We also present results from linear probability models (using robust standard errors) which have easily interpretable coefficients. This approach also allows equations explaining different types of variables to be compared which is necessary when working out direct and indirect effects (Table 5) of governance type. 
The explanatory variables for the loyalty and job security equations include the set of HRM practice variables, p. Here we have six HRM practices, as discussed above.

Determinants of these six types of practice, in regressions analogous to our model's equation (1), are given in Appendix Table 1. As for the other controls, we use an extensive set of individual characteristics common (e.g. Heywood et al 2007) in studies of job satisfaction.

We also control for commonly-used workplace characteristics including whether it is foreignowned, it is whether publicly listed, as well as its size. A final interesting characteristic is whether or not the workplace is a single establishment. In some cases this variable has marked influence because it is highly correlated with the family-owned and managed type, and so is difficult to interpret on its own.

Worker loyalty. Results are given in Table 2a. Column (1) controls only for worker characteristics, and in this specification we see the average level of loyalty is significantly higher in the FOM category, and lower in the public sector. The significant positive coefficient for workers in the FOM category remains as we bring in workplace practices and controls in column (2). However, in column (3) we see that controlling for single workplace absorbs the effect (though not for public sector workers). Evidently the single workplace characteristic of most (69\% - see Table 1b) FOM businesses of itself engenders loyalty. This effect cannot simply be picking up size, which is already controlled, but perhaps stands for something like the uniqueness of the business, and is best not separately controlled. We therefore concentrate on column (2) which does not control for uniqueness.

Table $2 \mathrm{~b}$ gives marginal effects for the governance type and management practice variables, based on column (2)'s specification. We see that workers in the FOM workplace are 3.43 percentage points more likely to be in the top category of loyalty. They are correspondingly less likely to be in the lower categories. To put these effects in perspective, we should note (Figure 1) that about $20 \%$ of workers put themselves in the top loyalty category. Therefore, the FOM workplace is associated with a sizeable advantage, approximately $15 \%$.

HRM policies which stand out in Table $2 \mathrm{~b}$ are training and high relative wages, both of which show a positive impact on loyalty which is understandable (see also Brown et al 2011). The fact that that loyalty-wage link is positive supports the Akerlof and Kranton (2005) view that loyalty and wages tend to be complements. This result is important, because it suggests that more loyal family-run workplaces need not pay less for given productivity, at least when effort is unmeasured.

As regards the training effect, to put this effect in perspective we must remember that the training variable's mean is around 0.30 (i.e., on average $30 \%$ of workers are trained for more than 2 days over the past year), with a similar standard deviation. Hence a standard deviation's change in the proportion trained would increase the proportion in the highest level of loyalty by about 4 percentage points (one-third of 12.6), a smaller amount though admittedly still considerable. Evidently,(formal) training is a potent way to improve loyalty, and it is interesting that family-run firms do less of it than other business types, ceteris paribus (Appendix Table 1). This said, we see that FOM workplaces still lead overall in stimulating worker loyalty.

Looking further at equation (3) in Table 2a, several coefficients have plausible signs. In particular, having supervisory duties is positively associated with loyalty $(0.245)$, as is being in a single independent workplace (0.190), perhaps for reasons of its uniqueness as noted above. Conversely, being a trade union member has a negative effect (-0.135), as does higher age ("burnout", -0.012), and being in a large firm (-0.029). On the other hand, company pension schemes are associated with less loyalty $(-0.086)$, which is puzzling (though 
this result also appears in the literature - see Heywood et al, 2002). Still, on the whole, the equation gives results which inspire confidence, and therefore we can take it that FOM workplaces generate more loyalty.

Job security. Tables $3 \mathrm{a}$ and $3 \mathrm{~b}$ show the results here. Feelings of job security correlate quite strongly with feelings of loyalty ( 0.336 at the individual level - see Notes to Table $2 a)$, but of course these variables capture different concepts.

Column (1) of Table 3a confirms the earlier description that both FOM and FNM types generate significantly higher feelings of job security $(0.159$, and 0.208$)$ than the private sector non-family reference group. This result is reduced (0.128 and 0.055$)$ in column (2) which includes HRM practices and other controls. Thus, these other variables diminish the direct effect of governance type, and in fact experimentation (not shown) suggests that the FOM's long term employment policies are particularly important. In other words, it is the long-term employment policies associated with FOM firms which are at the bottom of their workers' feeling of enhanced job security. Appendix Table 1 confirms this impression, since the equation explaining the long term employment policy variable shows that it is strongly linked (0.127) to FOM workplaces after controlling for many other variables. A long-term employment policy is also positively linked, though more weakly, to the FNM type.

It is of interest to note that Table 3a's results do not show that public sector workplaces generate feelings of job security that are higher than the private non-family sector. This result appears paradoxical, given that workers in the public sector face much less danger of workplace closure (Table 1b), and implies that closure per se is not all that important.

Moreover, the variable indicating a policy of guaranteed job security, which is a feature of the high unionism (Appendix Table 1) found in the public sector, is in fact significantly negatively related (-0.024) to felt job security. Overall, therefore, our findings support the argument of Miller et al (2008) that family-owned companies generate feelings of inclusion.

Table $3 \mathrm{~b}$ shows the marginal effects. We see that the FNM type generates strong feelings of security, with 3.68 percentage points more workers in the highest security category compared to the reference group of non-family private sector workplaces. The FOM type has a smaller effect, 2.0 percentage points, but this effect becomes larger, 2.51, as shown in the third row, if we do not control for the long-term employment policy variable. As can be seen this variable itself has marked effects, raising the percentage of workers in the top category by 5.24 points. These effects are all quite large, given that only around $20 \%$ of workers (Figure 1) put themselves in the top category.

Considering the other variables, we see that a practice of high training in the workplace generates strongly positive feelings of job security, just as it did for loyalty. Again, we must remember that the variation of this training variable in practice is only likely to be around 0.3 (its standard deviation), bringing its contribution to the upper security category down to a more reasonable 3 percentage points. A high relative wage, it is interesting to note, works the opposite way, reducing job security, just as do innovative HRM methods. Evidently both these practices make workers feel stressed, even if they are working harder.

A related aspect of stability is worker years of service in the workplace, or tenure. Table 1a shows that tenure is lower in family-owned workplaces, and this difference remains in regressions shown in column (3) of Table $3 a$. Tenure is significantly higher, by about 3/4 of a year in the public sector than the private sector non-family reference group. The two familyownership types have about half a year less tenure than the reference group. Again, it is revealing that the family-owned types, which have lowest tenure, generate the highest feelings of loyalty and job security. The suggestion is that worker turnover in these companies is 
efficient - weeding out the bad performers (Siebert and Zubanov 2009) with whom familyrun businesses can afford to experiment since job security restrictions and unionism are lower.

Workplace performance. Here we use an ordered probit on the same lines as for the loyalty and job security regressions:

$$
\mathrm{y}_{\mathrm{j}}=\alpha+\mathbf{A t}_{\mathrm{j}}+\mathbf{B f}+\mathbf{G p}+\mathbf{D z}+\mathrm{e}_{\mathrm{j}}
$$

where $y^{*}$ is a latent unobserved performance variable for the $\mathrm{j}$-th workplace, which we replace with a 4-category index, $\mathrm{e}_{\mathrm{j} i}$ is the error term, and the other variables are defined already in equation 3. As noted already, we use three measures of performance - finance, quality and labour productivity - as judged by workplace managers.

These regressions correspond to equation (3) of our model. The results are best seen as exploratory, indicating associative patterns rather than true causality, since workplace performance is the outcome of a complex system of decisions, and it is difficult in a crosssection such as the WERS to find exogenous variables. For example, a link between financial performance and job security could result from financially secure workplaces being able to offer security, rather than job security causing better performance. Still, so long as we are aware of their limitations, the patterns revealed in Table $4 \mathrm{a}$ are interesting.

Table 4a suggests that family ownership generally has beneficial direct effects on relative performance, that is, even holding constant worker feelings and HRM practices. To get the full family-ownership effect, we must add together the direct effect, plus effects on worker feelings and performance, if any, associated with family-ownership practices, which we will do in Table 5. For the moment, let us note that column (1) seems to give a large effect (0.345) for the FNM type, and also quite large (0.238) for the FOM type. These effects are easier to interpret in the linear probability model, where the FNM category for example, has 0.231 added to the private sector non-family reference category's 2.53 (see Table $1 \mathrm{~b}$ ), implying approximately $10 \%$ better performance. There appear to be no direct effects as regards relative productivity. However, as regards quality, the FOM type again has a positive direct effect (0.351), or 0.188 in linear probability terms, which translates into a $10 \%$ improvement over the non-family reference type.

The magnitude of effects can also be gauged from Table $4 \mathrm{~b}$, which presents marginal effects. Panel I gives results for financial performance, and we see that both family-owned types do better than the non-family private reference group. In other words, taking the top row, the proportion of FNM workplaces in the top category is 6.30 percentage points higher than the reference group. The percentage of the FOM type in the top category is 3.97 points higher. These are large effects given that only about $12 \%$ of workplaces are in the top group.

Looking down the rows at the effects of worker feelings, we see that workplace job security appears powerful, with a unit increase in average feelings implying an increase of $5.31 \%$ points in the workplace's chances of being in the top performance category. However, to put this effect in perspective, FOM workplaces are only 0.1 units higher (Table 1b) than non-family, so the contribution in practice can only be about $0.53 \%$ points. The long-term employment policy also makes a difference, with a workplace saying "yes" to this policy increasing its chances of being at the top by 2.54 points. Finally, the relative wage can also have a strong effect, but this is reduced in practice by the small differences (Table 1b) in relative wages among our governance types. Certainly what can be said is that raising the relative wage appears to be a powerful instrument for increasing financial performance presumably because of its incentive effects.

Panels II and III perform the same exercise for the productivity and quality dimensions of performance, so we can be brief. Panel II, for productivity, shows that it is the public sector 
which emerges as superior, with a $5.67 \%$ point greater chance of being in the top group (though the coefficient is insignificant in Table 4a). The private sector categories appear all to be similar. Going down the rows, we see that worker feelings do not seem to be important, but several management practices are. In particular, it is reassuring to see that as the relative wage increases, so does productivity (as is necessary if financial performance is to benefit).

Panel III, for quality, shows that the FOM type is outstanding, with a $10.77 \%$ point higher probability of being in the top category. Looking down the rows, we see that worker loyalty is important here (9.91\% in the top), as is the inclusive long-term employment policy (4.28\% in the top).

\section{Discussion and Conclusions}

This paper has aimed to test for advantages in the employment relations field of family-owned company governance using the WERS 2004. Two principal advantages are posited in the literature: first, that family-ownership brings a tighter owner-manager link with less principalagent problems, which leads to more effective (entrepreneurial) monitoring of management and workers. Training within the family also develops such monitoring. Second, familyownership is said to bring longer horizons ("patient capital"), leading to expectations of longterm employment, and thus greater loyalty and real job security. These feelings of loyalty and job security are beneficial in themselves, as evidence of good treatment, and should also confer benefits in terms of company performance.

Our definition of family ownership naturally depends upon the WERS questions which ask about $50 \%$ or more ownership. In addition, we know whether there is active family management. Hence we consider family-owned and managed (FOM) workplaces separately from other family-owned but non-family managed (FNM) workplaces. Of necessity, due to restrictions in the WERS questions, we include in the non-family group all non-corporate businesses including partnerships and sole proprietorships. This inclusion is reasonable since these businesses are unlikely yet to have developed the intergenerational strategy which is the core of the longer horizons posited for family-ownership governance.

At a basic level, without controls (Figure 1, and Tables 1a-b), we have found that our family-run group of workplaces differ considerably from other workplaces (including the public sector) in that they have significantly higher average scores for worker feelings of job security and loyalty. In addition, their industrial and regional distribution differs, being weighted more towards manufacturing, outside the prosperous South East. FOM organisations also tend to be quite small, averaging 3-400 employees (20 per workplace), compared to over 5,000 employees (30 per workplace) s for FNM organisations, and even more for the private sector non-family category. Finally, as regards HRM procedures, they are less likely to give guarantees of job security, but more likely informally to support long-term employment in the organisation. As regards survival, we find that workplace survival rates are similar for the FOM, FNM and other groups. Thus the posited longer horizon of the FOM company does not show itself in longer-lived workplaces.

This finding needs to be taken with our second result, for worker feelings of job security and loyalty (Tables $2 \mathrm{~b}$ and $3 \mathrm{~b}$ ), which are significantly stronger in the FOM and FNM workplaces, controlling for many other factors. At the same time, we find that public sector workers do not feel particularly secure or loyal, despite the longevity of their workplaces - and their longer tenure. This result suggests that it is worker treatment rather than workplace survival that matters. A significant difference in terms of treatment (Table 1b) appears to be family run companies" "inclusivity" as shown by their firmer support for longterm employment in the organisation. 
As regards performance, our results give a clear advantage to the family-run group as regards self-assessed financial and quality performance (Tables $4 \mathrm{a}$ and $4 \mathrm{~b}$ ), though not labour productivity. While these are soft variables, we do find a plausible pattern, with loyalty, job security and other inclusive family-run management practices such as emphasis on long-term jobs playing a part. This finding is clearly related to the longer horizons which are advanced as the distinguishing characteristic of family-run companies in James's (1999) quotation with which we began. Interestingly, while non-family managers in the FNM group might be said to give an advantage as regards financial performance, it is family managers in the FOM group which give the advantage as regards quality. Thus our results do not support the view current in the literature (see Bloom and Van Reenen, 2007) that the family manager need be worse.

Having established that family-run FOM and FNM workplaces have relatively good financial and quality performance, as well as higher worker loyalty and security, it is still important to track down the management practices which lead to this result. Our results are summarised in Table 5. As can be seen, HRM practices and worker feelings associated with FOM and FNM types explain a reasonable fraction of the total effect. For example, for the FNM group, as regards financial performance, the total FNM effect - in linear terms - is 0.22 , meaning that the FNM type adds 0.22 points to the private sector non-family average of about 2.5 (i.e., about 10\%). Admittedly, the direct (unexplained) effect, 0.23, is most important, but other HRM factors also contribute, for example, with worker security adding 0.03 , which is about $10 \%$ of the total, and the (lack of) innovative HRM policies subtracting -0.03. Again, as regards the good FOM quality performance, 0.22 , family-related HRM practices explain about 0.03 , or 15

Table 5 suggests that good employment relations practices make a useful contribution to FOM and FNM business performance. We see that high worker feelings of job security and/or loyalty add around 10 of the total for each of the finance and quality measures. Additionally, the "inclusive" FOM and FNM policy for employees to expect long-term employment adds an extra 5 to $10 \%$. Note that this effect is additional to the long-term employment policy's effect in helping raise worker job security, which is included under the worker job security row. Interestingly, it also appears that some HRM practices do not contribute much to performance, in particular working hours practices, guaranteed job security, and high formal training (however, they are important for worker feelings of loyalty and security).

To conclude, inclusive HRM practices are effective, and can reasonably be linked to family-run businesses' long horizons and management flexibility. These practices are more easily achieved with family control, and hence give a sort of unique selling point. Public sector management practices, for their part, appear to have disadvantages. This finding again is reasonable given the lack of competitive pressures to improve in the public sector. Therefore, to answer our opening question, family owned management practices confer advantages by improving worker loyalty and job security, and thence firm performance. These advantages remain in equilibrium, since adoption of inclusive HRM is difficult without an effective family entrepreneur to rally around. Still, good HRM practices explain only a part of the family-ownership performance advantage, and further research is needed into other contributory factors.

\section{References}

Akerlof G. and R. Kranton, 2005. "Identity and the economics of organizations", Journal of Economic Perspectives, 19: 9-32.

Anderson R and D Reeb. 2003. "Founding family ownership and firm performance: Evidence from the S\&P 500”. Journal of Finance, 58: 1301-1328. 
Arregle J, M Hitt, D Simon and P Very, 2007. "The development of organizational social capital: attributes of family firms", Journal of Management Studies, 44: 73-95.

Barnes L and S Hershon, 1976. "Transferring power in the family business", Harvard Business Review, 54: 105-114.

Barth E, T Gulbransen and P Schone. 2005. "Family ownership and productivity: the role of owner-management", Journal of Corporate Finance, 11: 107-127.

Bassanini, A., T. Breda, E. Caroli and A. Reberioux, 2010. "Working in family firms: less paid but more secure?" Paris School of Economics Working Paper 2010-40.

Bennedsen, M, K Nielsen, F Perez-Gonzalez and D Wolfenzon. 2007. "Inside the family firm: the role of families in succession decisions and performance", Quarterly Journal of Economics, 122: 647-691.

BIS, 2010. Small and Medium-sized Enterprise Statistics for the UK and Regions 2009, London: Department for Business Innovation and Skills.

Bjuggren $\mathrm{P}$ and L Sund, 2001. "Strategic decision making in intergenerational successions of small- and medium-size family-owned businesses", Family Business Review, 14: 1123.

Bjuggren P and L Sund, 2005. "Organization of transfers of small and medium-sized enterprises within the family: tax law considerations", Family Business Review, 18: 305-19.

Bloom N and J Van Reenen, 2007. "Measuring and explaining management practices across firms and countries", Quarterly Journal of Economics, 122: 1351-1408.

Boycko M, A Shleifer and R Vishny, 1996. "A theory of privatisation", Economic Journal, 106: 309-19.

Brown S, J. McHardy, R McNabb and K Taylor, 2011. "Workplace performance, worker commitmenr and loyalty", IZA Discussion Paper 5447, January.

Carlson D, N Upton and S Seaman, 2006. "The impact of human resource practices and compensation design on performance: an analysis of family-owned SMEs", Journal of Small Business Management, 44: 531-43.

Carrasco-Hernandez A, and G Sanchez-Marin, 2007. "The determinants of employee compensation in family firms: empirical evidence", Family Business Review, 20: 215228.

Chami, R, 1999. "What's different about family businesses?", IMF working paper, WP/01/70.

Chaplin J., J. Mangla, S. Purdon, and C. Airey, 2005. The Workplace Employment Relations Survey (WERS) 2004, Technical Report, (Cross-section and Panel Surveys), London: Department of Trade and Industry.

Chua J, J Chrisman and P Sharma, 2003. "Succession and nonsuccession concerns of amily firms and agency relationship with nonfamily managers", Family Business Review, 16: 89-105.

Chua J, J Chrisman and E Chang, 2004. "Are family firms born or made? An exploratory investigation”, Family Business Review, 17: 37-54.

Cleves M., W. Gould and R. Gutierrez, 2004. An Introduction to Survival Analysis Using Stata, College Station, Texas: Stata Press.

Colombier N. and D. Masclet, 2008. "Intergenerational Correlation in Self Employment: Some Further Evidence from French ECHP Data", Small Business Economics, 30: 423-37.

Cully M., S. Woodland, A. O'Reilly and G. Dix, 1999. Britain at Work - As Depicted by the 1998 Workplace Employee Relations Survey, London: Routledge.

Daniel K., and W S Siebert, 2005. "Does employment protection reduce the demand for unskilled labour?" International Economic Journal, 19: 1-26.

Demassis A., J. Chua and J. Chrisman, 2008. "Factors preventing intra-family succession", Family Business Review, 21: 183-99. 
Department of Trade and Industry. 2005 Workplace Employment Relations Survey: CrossSection, 2004 [computer file]. 1st ed. Colchester: The Data Archive [distributor], 21 December 2005. SN: 5294.

Dunn T. and D. Holz-Eakin, 2000. "Financial capital, human capital and transition to selfemployment: evidence from intergenerational links", Journal of Labor Economics, 18(2): 282-305.

Fairlie R. and A. Robb, 2007. "Families, human capital, and small business: evidence from the characteristics of business owners survey", Industrial \& Labor Relations Review, 60: $225-45$.

GEEF, 2009. Annual Report, Brussels: European Group of Owner Managed and Family Enterprises.

Greene, W, 2004. Econometric Analysis, New York: Prentice Hall.

Habbershon T, M Williams and I MacMillan, 203. "A unified systems perspective of family firm performance", Journal of Business Venturing 18: 451-65.

Harris R, R Reid, and R McAdam, 2004. "Consultation and communication in family businesses in Great Britain”, International Journal of Human Resource Management, 15: 1424-1444.

Heywood J, W S Siebert, and X Wei, 2002. "Worker sorting and job satisfaction: The case of union and government jobs", Industrial \& Labor Relations Review, 55: 595-609.

Heywood J, W S Siebert, and X Wei, 2007. "The implicit wage costs of family friendly work practices", Oxford Economic Papers, 59: 275-300.

IFB. 2008. The UK Family Business Sector. London: Institute for Family Business.

James H, 1999. "Owner as manager, extended horizons and the family firm". International Journal of the Economics of Business, 6: 41-55.

Kersley, B, C. Alpin, J. Forth, A. Bryson, H. Bewley, G. Dix, and S. Oxenbridge. 2005. Inside the Workplace: First Findings from the 2004 Workplace Employment Relations Survey, Abingdon: Routledge.

Klein S, J Astrachan, K Smymios, 2005. "The F-PEC scale of family influence: construction, validation and further implication for theory", Entrepreneurship Theory and Practice, 30: 321-39.

Kotey B and C Folker, 2007. "Employee training in SMEs: effect of size and firm type family and nonfamily", Journal of Small Business Management, 45: 214-238.

Leana C and H Van Buren, 1999. "Organizational social capital and employment practices", Academy of Management Review, 24: 538-55.

Le Breton-Miller I, D Miller and L Steier, 2004. "Toward an integrative model of effective FOB succession", Entrepreneurship Theory and Practice, 29: 305-38.

Miller D, I Le Breton-Miller and B Scholnick, 2008. "Stewardship vs. stagnation: an empirical comparison of small family and non-family businesses", Journal of Management Studies, 45: 51-78.

Michelacci C and O Silva, 2008. "Why so many local entrepreneurs?", Review of Economics and Statistics, 89: 615-33.

Mueller H and T Phillipon, 2006. "Family firms, paternalism and labor relations", NBER working paper 12739, Cambridge, MA: National Bureau of Economic Research.

Perez S, A Llopis and J Llopis, 2004. "The determinants of survival of Spanish manufacturing firms", Review of Industrial Organization, 25: 251-73.

Postel-Vinay F, and H Turon, 2007. "The public pay gap in Britain: Small differences that (don't?) matter", Economic Journal, 117: 1460-1503.

Poutziouris P, 2006. The UK Family Business PLC Economy. London: Institute for Family Business.

Reid, R. and J. Adams, 2001. "Human resource management - a survey of practices within family and non-family firms", Journal of European Industrial Training, 25: 310-20.

Schultze W, M Lubatkin and R Dino, 2003. "Towards a theory of agency and altruism in family firms", Journal of Business Venturing, 18: 473-90. 
Siebert, W S and N. Zubanov, 2009. "Searching for the Optimal Level of Employee Turnover: A Study of a Large UK Retail Organization", Academy of Management Journal, Vol. 52: 294-313.

Small Business Service, 2005. Annual Survey of Small Businesses: UK, 2005, produced by Institute for Employment Studies, URN 06/389a.

Sraer D, and D Thesmar, 2007. "Performance and behaviour of family firms: evidence from the French stock market", Journal of the European Economic Association, 5: 709-51.

Taylor M, 1996. "Earnings, independence or unemployment: why become self-employed?", Oxford Bulletin of Economics and Statistics, 58(2): 253-66.

Villalonga B and R Amit, 2006. "How do family ownership, control and management affect firm value?", Journal of Financial Economics, 80: 385-417.

Werner S, H Tosi and L Gomez-Meiia, 2005. "Organizational governance and employee pay: how ownership structure affects the firm's compensation strategy", Strategic management Journal, 26: 377-384.

Westhead P and M Cowling, 1998. "Family firm research: the need for a methodological rethink", Entrepreneurship Theory and Practice, 23: 31-56.

Westhead P and C Howorth, 2006. "Ownership and management issues associated with family-owned firm performance and company objectives", Family Business Review, 19: 301-16.

Williams, R., 2006. "Generalised ordered logit/partial proportional odds models for ordinal dependent variables", Stata Journal, 6: 58-82. 

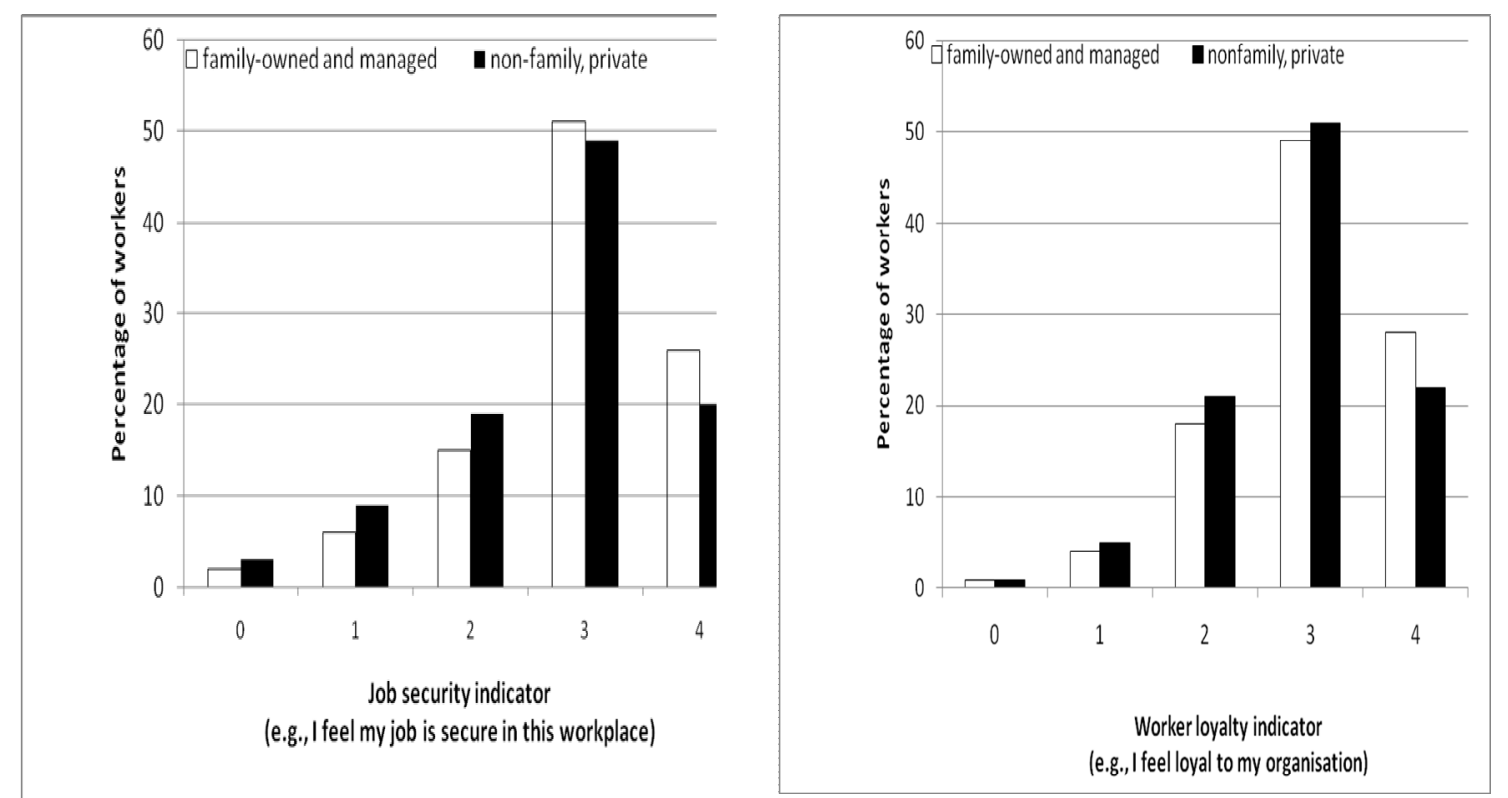

Figure 1: Worker Loyalty/Security in FOM Workplaces Contrasted with Non-Family

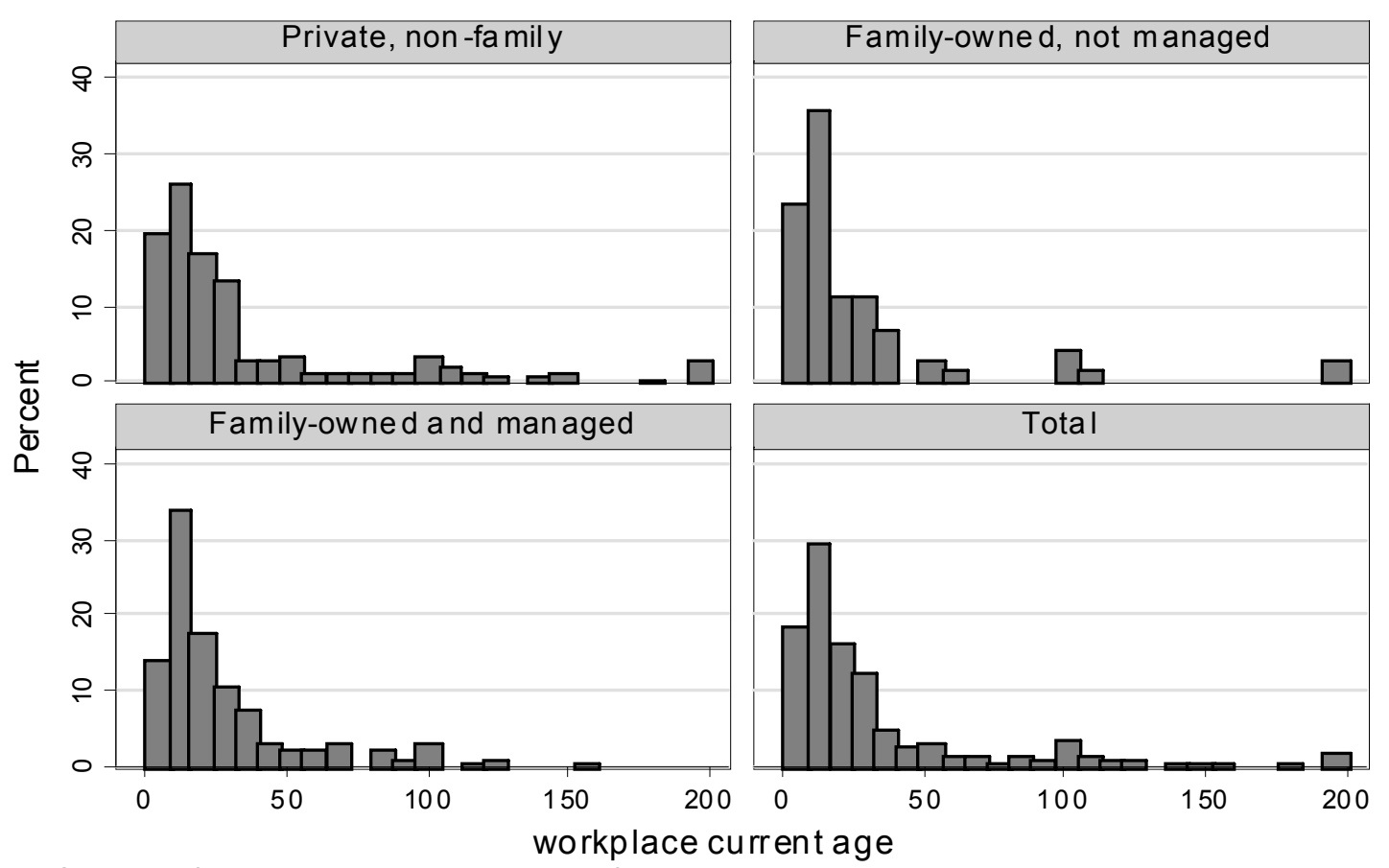

Graphs by family owned and managed and family not managed

Figure 2: Distribution of Workplace Ages 


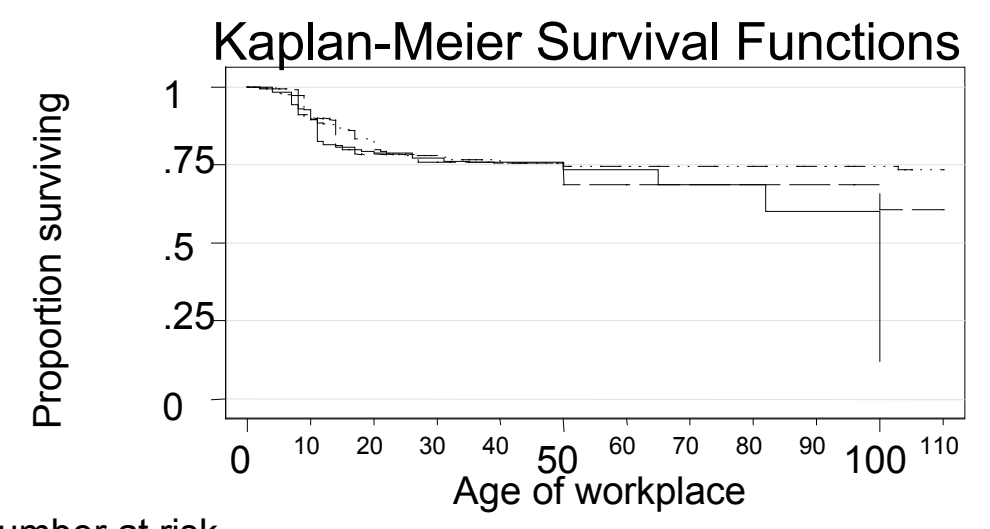

family owned \& managed family, not managed nonfamily (excl. publicLCs)

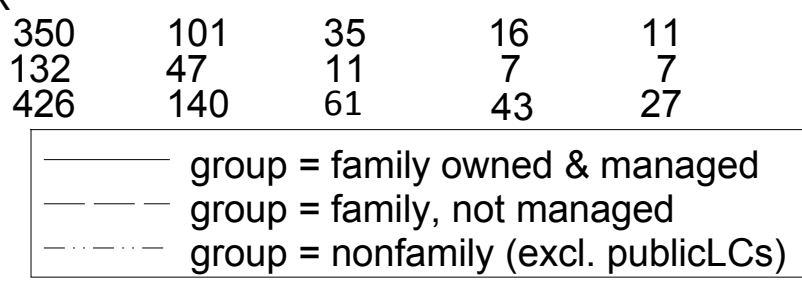

Note: weighted data

\section{Figure 3: Kaplan-Meier Survival Functions}


Table 1a Family Businesses - Numbers, Sizes and Legal Status

\begin{tabular}{|l|c|c|c|c|}
\hline & Public sector & $\begin{array}{c}\text { Private sector, } \\
\text { non-family }\end{array}$ & $\begin{array}{c}\text { Family-owned, not } \\
\text { family managed } \\
\text { FNM }^{\mathrm{b}}\end{array}$ & $\begin{array}{c}\text { Family-owned } \\
\text { and managed } \\
\text { FOM }^{\mathrm{b}}\end{array}$ \\
\hline Public limited company (PLC) & NA & $31 \%$ & 29 & 6 \\
\hline Private limited company & NA & 35 & 71 & 93 \\
\hline $\begin{array}{l}\text { Partnership (inc. limited liability } \\
\text { partnership) / self-proprietorship }\end{array}$ & NA & 23 & -- & -- \\
\hline Charity, cooperative & NA & 10 & -- & -- \\
\hline $\begin{array}{l}\text { No. workplace observations, } \\
\text { workplace weights (total=2,295) }\end{array}$ & $\begin{array}{c}(13 \%) \\
(51 \%)\end{array}$ & $\begin{array}{c}221 \\
(10 \%)\end{array}$ & $\begin{array}{c}601 \\
(26 \%)\end{array}$ \\
\hline $\begin{array}{l}\text { Approximate employment in } \\
\text { average "organisation", }\end{array}$ & NA & over 10,000 & $5-10,000$ & $3-400$ \\
\hline $\begin{array}{l}\text { No. worker observations, worker } \\
\text { weighted (total =23,012) }\end{array}$ & $\begin{array}{c}6,112 \\
(26 \%)\end{array}$ & $\begin{array}{c}11,941 \\
(52 \%)\end{array}$ & $\begin{array}{c}1,719 \\
(7 \%)\end{array}$ & $\begin{array}{c}3,240 \\
(14 \%)\end{array}$ \\
\hline
\end{tabular}

Memo: the number of enterprises with employees in the UK (BIS, 2010) is about $1.2 \mathrm{~m}$.; $0.8 \mathrm{~m}$. of these employ $<5$ workers each, while the largest 3000 enterprises employing $>500$ account for $8.1 \mathrm{~m}$.

Source: 2004 WERS - sample excludes workplaces smaller than 5.

Notes: a) Private sector non-family includes all partnerships and sole proprietorships who were not asked the family ownership questions in 2004.

b) Family-owned means that a single individual or family owns as least $50 \%$ of the company.

c) Family owned and managed (FOM) means that, in addition to family ownership, some of the controlling owners are actively involved fulltime in the day-to-day management of the workplace. If a family-owned workplace is not managed by one of the owners, we assume it is non-family managed (denoted FNM)

d) Workplace weighting is required to allow for over-sampling of larger workplaces, and is achieved using the weights and stratification information supplied with the dataset.

e) Employment covers total employment in the organisation to which the workplace belongs. Figures are approximate, since the WERS reports figures for 12 increasingly broad categories, of the order of 10,000 to 20,000 for larger organisations, top-coded at $100 \mathrm{k}$. 
Table 1b: Descriptive Statistics for the Main Variables

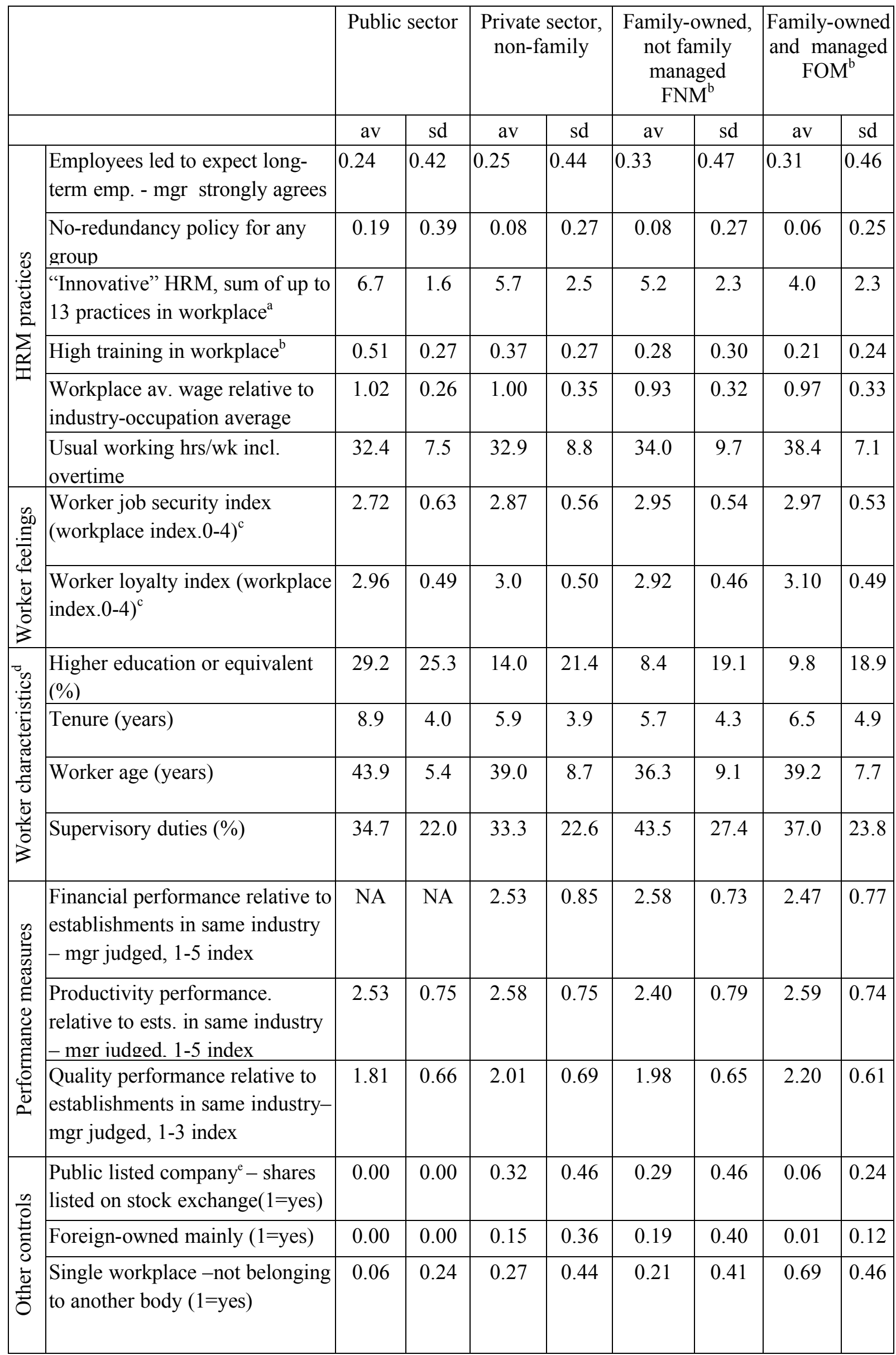




\begin{tabular}{|c|c|c|c|c|c|c|c|c|c|}
\hline & $\begin{array}{l}\text { Employees on payroll at } \\
\text { workplace }\end{array}$ & 60.8 & 247.8 & 32.0 & 111.7 & 28.3 & 67.8 & 18.5 & 36.5 \\
\hline & $\begin{array}{l}\text { Firm age (years at address or } \\
\text { previous addresses) }\end{array}$ & 45.6 & 40.1 & 30.5 & 36.1 & 22.1 & 32.5 & 21.4 & 24.9 \\
\hline & Market orientation - UK & NA & NA & 0.86 & 0.34 & 0.89 & 0.31 & 0.88 & 0.33 \\
\hline & $\begin{array}{l}\text { Degree of Competition (manager } \\
\text { assessed, } 1=\text { high; } 0=\text { low) }\end{array}$ & NA & NA & 0.71 & 0.45 & 0.84 & 0.37 & 0.74 & 0.44 \\
\hline & $\begin{array}{l}\text { Trade union at workplace } \\
(1=y e s)\end{array}$ & 0.56 & 0.50 & 0.12 & 0.33 & 0.03 & 0.17 & 0.03 & 0.18 \\
\hline & $\begin{array}{l}\text { Pension scheme for largest } \\
\text { occupational group (1=yes) }\end{array}$ & 0.94 & 0.23 & 0.62 & 0.49 & 0.61 & 0.49 & 0.36 & 0.48 \\
\hline & $\begin{array}{l}\text { Degree of communication } \\
\text { (workplace index. } 1-3)^{f}\end{array}$ & 2.66 & 0.53 & 2.39 & 0.71 & 2.35 & 0.61 & 1.87 & 0.67 \\
\hline & Dismissal rate & 0.00 & 0.02 & 0.04 & 0.11 & 0.05 & 0.12 & 0.02 & 0.07 \\
\hline & Redundancy rate & 0.00 & 0.02 & 0.01 & 0.05 & 0.01 & 0.03 & 0.01 & 0.08 \\
\hline & Suspension rate & 0.01 & 0.03 & 0.02 & 0.07 & 0.03 & 0.11 & 0.01 & 0.06 \\
\hline \multirow{13}{*}{ 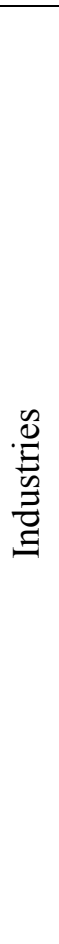 } & Manufacturing & 1 & & 8 & & 13 & & 21 & \\
\hline & Electricity/gas/water & 0 & & 0 & & 0 & & 0 & \\
\hline & Construction & 1 & & 2 & & 3 & & 14 & \\
\hline & Wholesale/retail & 0 & & 24 & & 53 & & 29 & \\
\hline & Hotel/restaurant & 2 & & 12 & & 10 & & 6 & \\
\hline & Transport/communication & 8 & & 5 & & 5 & & 3 & \\
\hline & Financial services & 0 & & 10 & & 0 & & 0 & \\
\hline & Other business services & 3 & & 19 & & 8 & & 16 & \\
\hline & Public administration & 17 & & 0 & & 0 & & 0 & \\
\hline & Education & 30 & & 1 & & 1 & & 1 & \\
\hline & Health & 26 & & 13 & & 4 & & 4 & \\
\hline & Other community services & 12 & & 7 & & 3 & & 5 & \\
\hline & Total & 100 & & 100 & & 100 & & 100 & \\
\hline \multirow{3}{*}{ 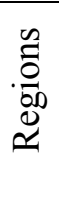 } & Region-London & 14 & & 11 & & 13 & & 9 & \\
\hline & Region - South east & 12 & & 14 & & 9 & & 13 & \\
\hline & Other regions & 74 & & 75 & & 78 & & 78 & \\
\hline
\end{tabular}

Source and Notes: see also Table 1a.

\section{Notes}

a) The" innovative" HRM index (based on Harris et al, 2004) includes the following variables based on whether the workplace: 1) has a formal individual grievance procedure, 2) has a formal written equal opportunities procedure,, 3 ) has a standard induction for the largest occupational group, 4) conducts personality or aptitude tests when filling vacancies, 5) conducts performance or competency tests when filling vacancies, 6 ) gives $>50 \%$ of non-managerial workers formal performance appraisal, 7 ) is accredited as an Investor in People, 8 ) requires $>50 \%$ of non-managerial workers to be multitasked, 9) judges the largest occupational group to have a lot of discretion over how they work, 10) has $>50 \%$ of the largest occupational group in formally designated teams, 11) uses quality circles, 12) has 
$>50 \%$ of non-managerial workers receiving performance pay, and 13 ) has $>50 \%$ of non-managerial workers receiving profit-related pay.

b) High training in workplace $=$ proportion of the workforce having $>=2$ days training arranged or paid by the firm in the past 12 months

c) The loyalty index is a Cronbach's alpha summation of 3 likert-scaled questions: "I share many of the values of my organisation", "I feel loyal to my organisation", and "I am proud to tell people who I work for", alpha $=0.849$. Similarly, the job security index is a Cronbach's alpha summation of 2 likertscaled questions: "I feel my job is secure in this workplace", and "How satisfied are you with job security on your job?", alpha $=0.888$.

d) Worker characteristics here are selected - our analysis also controls for other characteristics including marital status, number of children, illness status, permanent/temporary contract, and ethnicity.

d) The public limited company question relates to the status of the establishment questioned, or the organisation of which it is a part.

e) Degree of communication is made up from 5 communication tools: notice boards, systematic use of management chain, suggestion schemes, regular newsletters, and regular emails to all employees. We score use of 3 or more tools $=3,2$ tools $=2$, and none $=1$. 
Table 2a: Family Ownership and Worker Loyalty

[Square bracketed terms are coefficients from a linear probability model]

\begin{tabular}{|c|c|c|c|}
\hline \multirow[t]{2}{*}{ Generalised ordered probit } & \multicolumn{3}{|c|}{ Loyalty indicator, 5 categories (1-5, least-most loyal) } \\
\hline & $(1)$ & $(2)$ & (3) \\
\hline $\begin{array}{l}\text { Family-owned, not family managed } \\
\text { (FNM) }\end{array}$ & -0.016 & $\begin{array}{c}0.001 \\
{[0.006]}\end{array}$ & -0.002 \\
\hline Family-owned and managed (FOM) & $0.129 * *$ & $\begin{array}{c}0.123^{* *} \\
{\left[0.082^{* *}\right]}\end{array}$ & $0.08^{*}$ \\
\hline $\begin{array}{l}\text { Public sector (Reference is private } \\
\text { sector non-family) }\end{array}$ & $-0.115 * *$ & $\begin{array}{l}-0.133 * * * \\
{[-0.081 * *]}\end{array}$ & $-0.088 *$ \\
\hline \multicolumn{4}{|l|}{ HRM Practices } \\
\hline High training in workplace & & $\begin{array}{c}0.549^{* * *} \\
{\left[0.400^{* * *}\right]}\end{array}$ & $0.538 * * *$ \\
\hline Workplace relative wages & & $\begin{array}{c}0.177 * * * \\
{[0.131 * * *]}\end{array}$ & $0.184 * * *$ \\
\hline Workplace av. working hours & & $\begin{array}{l}-0.006^{* *} \\
-0.004 * *]\end{array}$ & $-0.006 * *$ \\
\hline Innovative HRM indicator & & $\begin{array}{c}-0.056 \\
{[-0.037]} \\
\end{array}$ & -0.059 \\
\hline Policy of guaranteed job security & & $\begin{array}{c}-0.005 \\
{[-0.003]}\end{array}$ & 0 \\
\hline $\begin{array}{l}\text { Policy leading employees to expect } \\
\text { long-term emp }\end{array}$ & & $\begin{array}{c}0.021 \\
{[0.014]}\end{array}$ & 0.027 \\
\hline \multicolumn{4}{|l|}{ Workplace controls } \\
\hline Public listed & & -0.039 & -0.008 \\
\hline Foreign-owned & & -0.012 & 0.012 \\
\hline Log workplace emp. & & $-0.024 * *$ & $-0.029 * * *$ \\
\hline Trade union at workplace & & 0.01 & 0.017 \\
\hline Pension scheme & & $-0.116^{* * *}$ & $-0.086^{* *}$ \\
\hline Dismissal rate & & -0.003 & -0.002 \\
\hline Redundancy rate & & $-0.008 * * *$ & $-0.008 * * *$ \\
\hline Suspension rate & & -0.001 & -0.001 \\
\hline Single workplace & & & $0.183 * * *$ \\
\hline \multicolumn{4}{|l|}{ Worker controls } \\
\hline Full-time contract & -0.03 & -0.012 & -0.012 \\
\hline Permanent contract & $0.078^{*}$ & 0.069 & 0.071 \\
\hline British & $-0.068^{*}$ & $-0.067^{*}$ & $-0.070 *$ \\
\hline Male & $-0.137 * * *$ & $-0.123 * * *$ & $-0.126^{* * *}$ \\
\hline Married & 0.031 & 0.055 & 0.05 \\
\hline Male*married & $0.103 * *$ & $0.086^{*}$ & $0.090 *$ \\
\hline Dependent children & 0.048 & 0.048 & 0.052 \\
\hline Male* children & 0.03 & 0.02 & 0.017 \\
\hline Illness indicator & $-0.075^{* * *}$ & $-0.078 * *$ & $-0.077 * *$ \\
\hline Supervisory duties & $0.252 * * *$ & $0.242 * * *$ & $0.245 * * *$ \\
\hline Age & $-0.013 * *$ & $-0.012 *$ & $-0.012 * *$ \\
\hline Age-squared & $0.000 * * *$ & $0.000 * * *$ & $0.000 * * *$ \\
\hline Workplace tenure & $-0.032 * * *$ & $-0.027 * * *$ & $-0.027 * * *$ \\
\hline Tenure-squared & $0.001 * * *$ & $0.001 * * *$ & $0.001 * * *$ \\
\hline
\end{tabular}




\begin{tabular}{|l|c|c|c|}
\hline Secondary education. & 0.006 & -0.02 & -0.02 \\
\hline Higher education & -0.043 & $-0.083^{* *}$ & $-0.084^{* *}$ \\
\hline Trade union member & $-0.122^{* * *}$ & $-0.137^{* * *}$ & $-0.135^{* * *}$ \\
\hline $\mathrm{N}$ & 20697 & 18750 & 18750 \\
\hline
\end{tabular}

Memo: correlation between worker feelings of loyalty and feelings of job security is 0.336 when taken across workers, and 0.485 when taken across firm averages.

Note: $* * *, * * *$ signify $1 \%, 5 \%$, and $10 \%$ significance levels. Ordered probit, with standard errors adjusted for clustering by workplace. Employee survey weights are used with strata and weight information supplied with the dataset .The regressions also control for region (dummies for the London area, South-East and East), industry (12 dummies) and occupation ( 9 dummies). 
Table 2b: Family Ownership and Worker Loyalty - Marginal Effects

(Effects calculated for equation 2 in Table 2a)

\begin{tabular}{|c|c|c|c|c|c|}
\hline & \multicolumn{5}{|c|}{ Loyalty indicator, 5 categories ( $0-4$, least-most loyal) } \\
\hline & level $=0$ & level $=1$ & level $=2$ & level $=3$ & level $=4$ \\
\hline $\begin{array}{l}\text { Family-owned, not family managed } \\
\text { (FNM) }\end{array}$ & 0.02 & 0.06 & 0.14 & 0.00 & -0.21 \\
\hline Family-owned and managed (FOM) & $-0.29 * *$ & $-0.95 * * *$ & $-2.34 * * *$ & $0.15^{*}$ & $3.43 * * *$ \\
\hline $\begin{array}{l}\text { Public sector (Reference is private } \\
\text { sector non-family) }\end{array}$ & $0.33 * * *$ & $1.06^{* * *}$ & $2.61^{* * *}$ & $-0.17 * *$ & $-3.83 * * *$ \\
\hline \multicolumn{6}{|l|}{ HRM practices } \\
\hline High training in workplace & $-1.33 * * *$ & $-4.32 * * *$ & $-10.7 * * *$ & $0.71 * *$ & $15.6^{* * *}$ \\
\hline Workplace relative wages & $-0.43 * * *$ & $-1.38 * * *$ & $-3.42 * * *$ & $0.22 * *$ & $5.00 * * *$ \\
\hline Workplace av. working hours & $0.01 * *$ & $.04 * *$ & $0.11 * *$ & -0.00 & $-0.16 * *$ \\
\hline Innovative HRM indicator & $-0.09 * * *$ & -0.08 & 0.08 & $0.92 * * *$ & $-0.67 * * *$ \\
\hline Policy of guaranteed job security & $-0.40 *$ & -0.495 & 1.92 & $2.40 *$ & $-3.42 * *$ \\
\hline $\begin{array}{l}\text { Policy leading employees to expect } \\
\text { long-term employment }\end{array}$ & -0.05 & -0.17 & -0.43 & 0.00 & 0.63 \\
\hline
\end{tabular}

Note: $* * *, * *, *$ signify $1 \%, 5 \%$, and 10\% significance levels. Generalised ordered probit,(Williams 2006) with standard errors adjusted for clustering by workplace. Employee survey weights are used with strata and weight information supplied with the dataset. The regressions also control for region (dummies for the London area, South-East and East), industry (12 dummies) and occupation (9 dummies). 
Table 3a: Family Ownership and Worker Job Security and Tenure

[Square bracketed terms are coefficients from a linear probability model]

\begin{tabular}{|c|c|c|c|}
\hline \multirow[t]{2}{*}{ Ordered probit } & \multicolumn{2}{|c|}{$\begin{array}{c}\text { Job security indicator, } 5 \text { categories } \\
(0-4, \text { least-most secure })\end{array}$} & \multirow{2}{*}{$\begin{array}{c}\begin{array}{c}\text { Tenure } \\
\text { (years) OLS }\end{array} \\
(3)\end{array}$} \\
\hline & (1) & $(2)$ & \\
\hline Family-owned, not family managed (FNM) & $0.159 * *$ & $\begin{array}{c}0.128 * * \\
{[0.102 * *]}\end{array}$ & $-0.603 *$ \\
\hline Family-owned and managed (FOM) & $0.208 * * *$ & $\begin{array}{l}0.055^{*} \\
{[0.037]}\end{array}$ & -0.391 \\
\hline $\begin{array}{l}\text { Public sector (Reference is private sector } \\
\text { non-family) }\end{array}$ & -0.016 & $\begin{array}{c}0.002 \\
{[0.018]}\end{array}$ & $0.728 * *$ \\
\hline \multicolumn{3}{|l|}{ HRM practices } & \\
\hline High training in workplace & & $\begin{array}{c}0.312 * * * \\
{\left[0.268^{* * *}\right]}\end{array}$ & $-1.095 * *$ \\
\hline Workplace relative wages & & $\begin{array}{c}-0.108 \\
{[-0.090]}\end{array}$ & -0.017 \\
\hline Workplace av. working hours & & $\begin{array}{c}0.001 \\
{[0.001]}\end{array}$ & -0.013 \\
\hline Innovative HRM indicator & & $\begin{array}{c}0.028 \\
{[0.016]}\end{array}$ & $-0.080^{*}$ \\
\hline Policy of guaranteed job security & & $\begin{array}{c}-0.024 * * * \\
{[-0.019 * * *]}\end{array}$ & 0.285 \\
\hline $\begin{array}{l}\text { Policy leading employees to expect long- } \\
\text { term emp }\end{array}$ & & $\begin{array}{c}0.194 * * * \\
{[0.160 * * *]}\end{array}$ & 0.041 \\
\hline \multicolumn{3}{|l|}{ Workplace controls } & \\
\hline Public listed & & -0.049 & 0.056 \\
\hline Foreign-owned & & $-0.120 * *$ & 0.273 \\
\hline Log workplace emp. & & -0.005 & $0.246 * * *$ \\
\hline Trade union at workplace & & -0.041 & $0.809 * * *$ \\
\hline Pension scheme & & $-0.091 * *$ & 0.293 \\
\hline Dismissal rate & & 0.004 & $-0.086 * * *$ \\
\hline Redundancy rate & & $-0.024 * * *$ & $0.046 * * *$ \\
\hline Suspension rate & & -0.002 & 0.007 \\
\hline Single workplace & & 0.06 & 0.022 \\
\hline \multicolumn{3}{|l|}{ Worker controls } & \\
\hline Full-time contract & $-0.058 * *$ & -0.012 & -0.125 \\
\hline Permanent contract & $0.623 * * *$ & $0.593 * * *$ & $2.576^{* * *}$ \\
\hline British & 0.057 & 0.051 & $0.448^{* *}$ \\
\hline Male & $-0.098 * * *$ & $-0.092 * *$ & 0.199 \\
\hline Married & 0.045 & 0.044 & $0.500 * * *$ \\
\hline Male*married & 0.04 & 0.047 & -0.357 \\
\hline Dependent children & 0.044 & 0.043 & 0.01 \\
\hline Male* children & -0.051 & -0.062 & 0.098 \\
\hline Illness indicator & $-0.124 * * *$ & $-0.121 * * *$ & 0.127 \\
\hline Supervisory duties & $0.187 * * *$ & $0.169 * * *$ & $1.965 * * *$ \\
\hline Age & $-0.054 * * *$ & $-0.052 * * *$ & $0.238 * * *$ \\
\hline Age-squared & $0.001 * * *$ & $0.001 * * *$ & -0.001 \\
\hline Workplace tenure & -0.004 & 0.009 & -- \\
\hline Secondary education. & $-0.130 * * *$ & $-0.140 * * *$ & $-0.695 * * *$ \\
\hline
\end{tabular}




\begin{tabular}{|c|c|c|c|}
\hline Higher education & $-0.174 * * *$ & $-0.183 * * *$ & $-1.788 * * *$ \\
\hline Trade union member & $-0.106^{* * *}$ & $-0.095 * * *$ & $2.507 * * *$ \\
\hline $\mathrm{N}$ & 21390 & 19458 & 19732 \\
\hline
\end{tabular}

Note: $* * *, * *, *$ signify $1 \%, 5 \%$, and $10 \%$ significance levels. Ordered probit, with standard errors adjusted for clustering by workplace. Employee survey weights are used with strata and weight information supplied with the dataset. The regressions also control for region (dummies for the London area, South-East and East), industry (12 dummies) and occupation (9 dummies). 
Table 3b: Family Ownership and Worker Job Security - Marginal Effects

(Effects calculated for column 2 in Table 3a)

\begin{tabular}{|c|c|c|c|c|c|}
\hline & \multicolumn{5}{|c|}{ Job security indicator, 5 categories ( $0-4$, least-most secure) } \\
\hline & level $=0$ & level $=1$ & level $=2$ & level $=3$ & level=4 \\
\hline $\begin{array}{l}\text { Family-owned, not family managed } \\
\text { (FNM) }\end{array}$ & $-0.79 * *$ & $-1.62 * *$ & $-1.84 * *$ & $0.57 * *$ & $3.68 * *$ \\
\hline Family-owned and managed (FOM) & $-0.43 *$ & $-0.88^{*}$ & $-1.00 *$ & 0.31 & $2.00^{*}$ \\
\hline $\begin{array}{l}\text { (FOM, excluding long-term } \\
\text { employment policy) }\end{array}$ & $-0.53 * *$ & $-1.10 * *$ & $-1.26^{* *}$ & $0.38^{*}$ & $2.51 * *$ \\
\hline $\begin{array}{l}\text { Public sector (Reference is private } \\
\text { sector non-family) }\end{array}$ & 0.10 & 0.20 & 0.23 & -0.07 & -0.45 \\
\hline \multicolumn{6}{|l|}{ HRM practices } \\
\hline High training in workplace & $-1.90 * * *$ & $-3.94 * * *$ & $-4.51 * * *$ & $1.40 * * *$ & $9.00 * * *$ \\
\hline Workplace relative wages & $0.67 *$ & $1.38^{*}$ & $1.58^{*}$ & $-0.49 *$ & $-3.1 *$ \\
\hline Workplace av. working hours & 0.00 & 0.00 & 0.00 & 0.00 & 0.00 \\
\hline Innovative HRM indicator & $0.15^{* * *}$ & $0.32^{* * *}$ & $0.362 * * *$ & $-0.11 * * *$ & $-0.72 * * *$ \\
\hline Policy of guaranteed job security & -0.18 & -0.36 & -0.42 & 0.13 & 0.83 \\
\hline $\begin{array}{l}\text { Policy leading employees to expect } \\
\text { long-term emp }\end{array}$ & $-1.13 * * *$ & $-2.30 * * *$ & $-2.61 * * *$ & $0.81 * * *$ & $5.24 * * *$ \\
\hline
\end{tabular}

Note: $* * *, * *, *$ signify $1 \%, 5 \%$, and $10 \%$ significance levels. Generalised ordered probit, with standard errors adjusted for clustering by workplace. Employee survey weights are used with strata and weight information supplied with the dataset. 
Table 4a: Family Ownership and Relative Financial, Quality and Productivity Performance

(Ordered probit regressions: categorical dependent variable, $1=$ lowest to 3 or $4=$ highest) [Square bracketed terms are coefficients from a linear probability model]

\begin{tabular}{|c|c|c|c|}
\hline & $\begin{array}{l}\text { Relative financial } \\
\text { performance, } \\
\text { 4categories, } \\
\text { 4=highest }\end{array}$ & $\begin{array}{l}\text { Relative } \\
\text { productivity } \\
\text { performance, } 4 \\
\text { categories, } \\
\text { 4=highest }\end{array}$ & $\begin{array}{l}\text { Relative } \\
\text { quality } \\
\text { performance, } 3 \\
\text { categories, } \\
\text { 3=highest }\end{array}$ \\
\hline & $\begin{array}{l}\text { Private sector } \\
\text { only }\end{array}$ & $\begin{array}{l}\text { Public plus } \\
\text { private }\end{array}$ & $\begin{array}{l}\text { Public plus } \\
\text { private }\end{array}$ \\
\hline & $(1)$ & $(2)$ & (3) \\
\hline Family-owned, not family managed (FNM) & $\begin{array}{c}0.345^{*} \\
{\left[0.231^{*}\right]}\end{array}$ & $\begin{array}{c}-0.067 \\
{[-0.048]}\end{array}$ & $\begin{array}{c}-0.136 \\
{[-0.081]}\end{array}$ \\
\hline Family-owned and managed (FOM) & $\begin{array}{c}0.238^{*} \\
{\left[0.179^{* *}\right]}\end{array}$ & $\begin{array}{c}0.014 \\
{[0.009]}\end{array}$ & $\begin{array}{c}0.351^{* *} \\
{\left[0.188^{* *}\right]}\end{array}$ \\
\hline $\begin{array}{l}\text { Public sector (Reference is private sector } \\
\text { non-family) }\end{array}$ & NA & $\begin{array}{c}0.292 \\
{[0.196]}\end{array}$ & $\begin{array}{c}-0.247 \\
{[-0.133]}\end{array}$ \\
\hline \multicolumn{4}{|l|}{ Worker feelings } \\
\hline Job security (workplace av.) & $\begin{array}{c}0.339 * * * \\
{[0.247 * * *]}\end{array}$ & $\begin{array}{c}0.107 \\
{[0.087]} \\
\end{array}$ & $\begin{array}{c}0.040 \\
{[0.034]} \\
\end{array}$ \\
\hline Loyalty (workplace av.) & $\begin{array}{c}-0.104 \\
{[-0.075]}\end{array}$ & $\begin{array}{c}0.087 \\
{[0.043]}\end{array}$ & $\begin{array}{c}0.341^{* *} \\
{\left[0.172^{* *}\right]}\end{array}$ \\
\hline \multicolumn{4}{|l|}{ HRM practices } \\
\hline Innovative HRM practices & $\begin{array}{c}0.084 * * * \\
{[0.060]}\end{array}$ & $\begin{array}{c}0.065^{*} \\
{\left[0.043^{* *}\right]}\end{array}$ & $\begin{array}{c}0.014 \\
{[0.008]}\end{array}$ \\
\hline Policy of guaranteed job security (yes $=1$ ) & $\begin{array}{c}0.271 \\
{[0.183]}\end{array}$ & $\begin{array}{c}0.215 \\
{[0.125]}\end{array}$ & $\begin{array}{c}0.121 \\
{[0.061]}\end{array}$ \\
\hline High training in workplace & $\begin{array}{c}-0.269 \\
{[-0.172]} \\
\end{array}$ & $\begin{array}{c}-0.275 \\
{[-0.152]}\end{array}$ & $\begin{array}{c}0.047 \\
{[0.031]}\end{array}$ \\
\hline $\begin{array}{l}\text { Policy leading employees to expect long- } \\
\text { term emp }\end{array}$ & $\begin{array}{c}0.161^{*} \\
{\left[0.116^{*}\right]}\end{array}$ & $\begin{array}{c}0.179 * * \\
{[0.254 * * *]}\end{array}$ & $\begin{array}{c}0.147 * * \\
{[0.174 * * *]}\end{array}$ \\
\hline Workplace relative wage & $\begin{array}{c}0.663^{* * *} \\
{\left[0.433^{* * *}\right]}\end{array}$ & $\begin{array}{c}0.382^{*} \\
{\left[0.249^{*}\right]}\end{array}$ & $\begin{array}{c}-0.200 \\
{[-0.104]}\end{array}$ \\
\hline Workplace av. working hours & $\begin{array}{c}-0.008 \\
{[-0.005]}\end{array}$ & $\begin{array}{c}-0.001 \\
{[0.000]}\end{array}$ & $\begin{array}{c}0.002 \\
{[0.001]}\end{array}$ \\
\hline \multicolumn{4}{|l|}{ Workplace controls } \\
\hline $\begin{array}{l}\text { Secondary education (workplace } \\
\text { proportion.) }\end{array}$ & -0.429 & $-0.552 * *$ & -0.058 \\
\hline Higher education (workplace proportion.) & -0.321 & -0.002 & $0.560^{*}$ \\
\hline Tenure (workplace av.) & $-0.060 * * *$ & -0.021 & $-0.035 * *$ \\
\hline Degree of communication-medium & $-0.555^{* * *}$ & $-0.317 *$ & -0.294 \\
\hline $\begin{array}{l}\text { Degree of communication-high (Reference } \\
\text { category - low) }\end{array}$ & $-0.392 *$ & -0.138 & -0.087 \\
\hline Log of establishment age & 0.082 & 0.020 & 0.016 \\
\hline Log of establishment size & $0.113^{* *}$ & -0.061 & 0.073 \\
\hline Foreign owned & $0.748 * * *$ & 0.156 & 0.099 \\
\hline Single establishment & -0.182 & $0.268^{*}$ & 0.168 \\
\hline Union membership & -0.101 & -0.309 & 0.203 \\
\hline
\end{tabular}




\begin{tabular}{|l|c|c|c|}
\hline Market orientation - UK & $0.369 * *$ & -0.027 & -0.036 \\
\hline Degree of Competition & -0.132 & -0.039 & -0.115 \\
\hline Observations & 1366 & 1127 & 1209 \\
\hline
\end{tabular}

Notes: ${ }^{* * *}, * *, *$ signify $1 \%, 5 \%$, and $10 \%$ significance levels. Standard errors are adjusted for clustering by workplace. Establishment survey weights are used with strata and weight information supplied with the dataset. Regressions include industry (12 dummies) and regional (4 dummies) controls.

The financial performance and productivity are converted to 4 categories by running the bottom 2 (a lot below average, plus below average) together; the quality measure is converted to 3 by running the bottom 2 together with the middle "about average for the industry". 
Table 4b: Marginal Effects - Relative Financial Performance

(Effects calculated from Table 4a )

Panel I: Financial performance, 4 categories (1-4, least-most) - private sector only

\begin{tabular}{|l|c|c|c|c|}
\hline $\begin{array}{l}\text { Ownership effect (reference private sector non- } \\
\text { family) }\end{array}$ & level=1 & level=2 & level=3 & level=4 \\
\hline Family-owned, not family managed (FNM) & $-4.65^{* * *}$ & $-7.16^{* * *}$ & $5.52^{* * *}$ & $6.30^{* * *}$ \\
\hline Family-owned and managed (FOM) & $-3.56^{* * *}$ & $-4.61^{*}$ & $4.20^{* * *}$ & $3.97^{* * *}$ \\
\hline Worker feelings & & & & \\
\hline Job security & $-5.35^{* * *}$ & $-6.33^{* * *}$ & $6.36^{* *}$ & $5.31^{* * *}$ \\
\hline Loyalty & 1.64 & 1.94 & -1.95 & -1.63 \\
\hline HRM practices & & & & \\
\hline Innovative HRM practices indicator & $-1.32^{* * *}$ & $-1.56^{* * *}$ & $1.57^{* * *}$ & $1.32^{* * *}$ \\
\hline Policy of guaranteed job security & $-3.79^{* *}$ & $-5.50^{* *}$ & $4.51^{* *}$ & $4.78^{*}$ \\
\hline Long-term employment policy & $-2.55^{* * *}$ & $-2.99^{* * *}$ & $3.01^{* * *}$ & $2.54^{* * *}$ \\
\hline High training in workplace & $4.24^{*}$ & $5.02^{*}$ & $-5.05^{*}$ & $-4.22^{*}$ \\
\hline Workplace relative wage & $-10.47^{* * *}$ & $-12.40^{* * *}$ & $12.46^{* * *}$ & $10.41^{* *}$ \\
\hline Workplace av. working hours & $0.13^{* *}$ & $0.15^{*}$ & $-0.15^{*}$ & $-0.13^{* *}$ \\
\hline
\end{tabular}

Panel II - productivity performance, 4 categories (1-4, least-most) - Private plus public

\begin{tabular}{|l|c|c|c|c|}
\hline $\begin{array}{l}\text { Ownership effect (reference private sector non- } \\
\text { family) }\end{array}$ & level=1 & level=2 & level=3 & level=4 \\
\hline Family-owned, not family managed (FNM) & 0.70 & 1.77 & -1.35 & -1.12 \\
\hline Family-owned and managed (FOM) & -0.14 & -0.37 & 0.27 & 0.24 \\
\hline Public sector & $-2.53^{* *}$ & $-7.94^{*}$ & $4.79^{* *}$ & $5.67^{*}$ \\
\hline Worker feelings & & & & \\
\hline Job security & -1.07 & $-2.85 \%$ & 2.07 & 1.85 \\
\hline Loyalty & -0.87 & $-2.31 \%$ & 1.68 & 1.50 \\
\hline HRM practices & & & & \\
\hline Innovative HRM practices indicator & $-0.66^{* * *}$ & $-1.74^{* * *}$ & $1.26^{* * *}$ & $1.13^{* * *}$ \\
\hline Policy of guaranteed job security & $-1.89^{* * *}$ & $-5.91^{* * *}$ & $3.69^{* * *}$ & $4.11^{* *}$ \\
\hline Long-term employment policy & $-1.81^{* * *}$ & $-4.74^{* * *}$ & $3.44^{* * *}$ & $3.11^{* * *}$ \\
\hline High training in workplace & $2.76^{*}$ & $7.35^{*}$ & $-5.34^{*}$ & $-4.77^{* *}$ \\
\hline Workplace relative wage & $-3.83^{* * *}$ & $-10.20^{* * *}$ & $7.42^{* * *}$ & $6.62^{* * *}$ \\
\hline Workplace av. working hours & 0.01 & 0.04 & -0.03 & -0.02 \\
\hline
\end{tabular}


Panel III - quality performance, 3 categories (1-3, least-most) - Private plus public

\begin{tabular}{|l|c|c|c|}
\hline Ownership effect (reference private sector non-family) & level=1 & level=2 & level=3 \\
\hline Family-owned, not family managed (FNM) & 3.53 & 0.30 & -3.83 \\
\hline Family-owned and managed (FOM) & $-8.22^{* * *}$ & $-2.55^{*}$ & $10.77^{* * *}$ \\
\hline Public sector & 6.58 & 0.24 & $-6.81^{*}$ \\
\hline Worker feelings & & & \\
\hline Job security & -1.00 & -0.17 & 1.17 \\
\hline Loyalty & $-8.48^{* * *}$ & $-1.43^{* * *}$ & $9.91^{* * *}$ \\
\hline HRM practices & & & \\
\hline Innovative HRM practices indicator & -0.34 & -0.06 & 0.40 \\
\hline Policy of guaranteed job security & -2.89 & -0.72 & 3.61 \\
\hline Long-term employment policy & $-3.66^{* * * *}$ & $-0.62^{* * *}$ & $4.28^{* * *}$ \\
\hline High training in workplace & -1.17 & -0.20 & 1.36 \\
\hline Workplace relative wage & $4.98^{* *}$ & 0.84 & $-5.82^{*}$ \\
\hline Workplace av. working hours & -0.04 & -0.01 & 0.05 \\
\hline
\end{tabular}

Source and Notes: see Table 4a. 
Table 5: Schematic links between Ownership Type, HRM, Worker Feelings and Performance

(coefficients from linear probability models; 0 denotes an insignificant coefficient)

\begin{tabular}{|c|c|c|c|c|c|c|c|}
\hline \multirow{2}{*}{\multicolumn{2}{|c|}{ Effects of govern }} & \multicolumn{2}{|c|}{$\begin{array}{c}\text { Family-owned, not } \\
\text { family managed } \\
\text { FNM }\end{array}$} & \multicolumn{2}{|c|}{$\begin{array}{c}\text { Family-owned and } \\
\text { managed } \\
\text { FOM }\end{array}$} & \multicolumn{2}{|c|}{ Public } \\
\hline & & Finance & Quality & Finance & Quality & Quality & $\begin{array}{c}\text { Produc } \\
\text { tivity }\end{array}$ \\
\hline \multicolumn{2}{|c|}{ Direct effect (from Table 4a) } & 0.23 & 0 & 0.18 & 0.19 & $-\dagger \dagger$ & $+\dagger \dagger$ \\
\hline \multirow{2}{*}{$\begin{array}{l}\text { Effects } \\
\text { via } \\
\text { feelings: }\end{array}$} & Worker loyalty & 0 & 0 & 0 & 0.01 & -0.001 & -0.004 \\
\hline & Worker job security & 0.03 & 0.01 & 0.01 & 0.001 & 0.003 & 0.001 \\
\hline \multirow{6}{*}{$\begin{array}{l}\text { Extra } \\
\text { effects } \\
\text { via } \\
\text { HRM: }\end{array}$} & $\begin{array}{l}\text { Policy of guaranteed } \\
\text { job security }\end{array}$ & 0 & 0 & 0 & & 0 & 0 \\
\hline & $\begin{array}{l}\text { Policy for } \\
\text { employees to expect } \\
\text { long-term emp }\end{array}$ & 0.02 & 0.02 & 0.01 & 0.02 & 0 & 0 \\
\hline & $\begin{array}{l}\text { Innovative HRM } \\
\text { indicator }\end{array}$ & -0.03 & 0 & 0 & 0 & 0 & 0 \\
\hline & $\begin{array}{l}\text { High training in } \\
\text { workplace }\end{array}$ & 0 & 0 & 0 & 0 & 0 & 0 \\
\hline & $\begin{array}{l}\text { Workplace relative } \\
\text { wages }\end{array}$ & -0.03 & 0 & 0 & 0 & 0 & 0 \\
\hline & $\begin{array}{l}\text { Workplace av. } \\
\text { working hours }\end{array}$ & 0 & 0 & & 0 & 0 & 0 \\
\hline \multicolumn{2}{|c|}{ TOTAL effect } & 0.22 & .03 & 0.20 & 0.22 & $-\dagger \dagger$ & $+\dagger \dagger$ \\
\hline
\end{tabular}

Source: Appendix 2 calculations. $\dagger \dagger$ positive (negative) public sector productivity (quality) is shown in Table 4b's marginal effects.

Notes: the direct effects of type are taken from the linear probability coefficients in square brackets in Table 4a, and are relative to private sector non-family workplaces. E.g., 0.22 for the FNM type, means that the FNM type adds 0.22 points to the private sector non-family average of about 2.5 (i.e., about $10 \%$ ). To these direct effects we can add beneficial FNM effects on performance exerted. e.g., via extra job security felt in FNM workplaces $(0.03)$. We also add/subtract extra effects via HRM (excluding HRM effects already taken into account via worker feelings). For example, the policy for employees to expect long-term employment adds 0.02 to financial performance, while the (less) innovative HRM policies subtract -0.03 . 
APPENDIX TABLE 1: DETERMINANTS OF SIX HRM PRACTICES

[Square bracketed terms are coefficients from a linear probability model]

\begin{tabular}{|c|c|c|c|c|c|c|}
\hline & $\begin{array}{c}\text { Guaranteed } \\
\text { job security } \\
\text { practice } \\
\text { (probit - } \\
\text { marginal } \\
\text { effects) } \\
\text { (1) }\end{array}$ & $\begin{array}{l}\text { Encourag- } \\
\text { ing long- } \\
\text { term emp } \\
\text { (probit - } \\
\text { marginal } \\
\text { effects) } \\
\text { (2) }\end{array}$ & $\begin{array}{c}\text { Innovative } \\
\text { HRM } \\
\text { practice } \\
\text { (OLS) } \\
\\
\text { (3) }\end{array}$ & $\begin{array}{l}\text { High } \\
\text { training } \\
\text { practice } \\
(\text { OLS) } \\
\\
(4)\end{array}$ & $\begin{array}{c}\text { Workplace } \\
\text { relative } \\
\text { wage } \\
\text { (OLS) } \\
\text { (5) }\end{array}$ & $\begin{array}{c}\text { Workplace } \\
\text { av. working } \\
\text { hours } \\
\text { (OLS) } \\
\\
\text { (6) }\end{array}$ \\
\hline $\begin{array}{l}\text { Family-owned, not } \\
\text { managed (FNM) }\end{array}$ & $\begin{array}{c}-0.006 \\
{[-0.001]}\end{array}$ & $\begin{array}{c}0.134^{*} \\
{\left[0.131^{*}\right]}\end{array}$ & $-0.401 *$ & -0.026 & $-0.084 *$ & 1.97. \\
\hline $\begin{array}{l}\text { Family-owned and } \\
\text { managed (FOM) }\end{array}$ & $\begin{array}{c}-0.016 \\
{[-0.013]}\end{array}$ & $\begin{array}{c}0.117^{*} \\
{\left[0.113^{*}\right]}\end{array}$ & 0.06 & $-0.084 * * *$ & -0.022 & $4.53 * * *$ \\
\hline $\begin{array}{l}\text { Public sector } \\
\text { (Reference is private } \\
\text { sector non-family) }\end{array}$ & $\begin{array}{c}0.021 \\
{[0.003]}\end{array}$ & $\begin{array}{c}-0.002 \\
{[-0.009]}\end{array}$ & -0.386 & $0.124 * *$ & 0.004 & $-2.82 * *$ \\
\hline $\begin{array}{l}\text { Guaranteed job } \\
\text { security practice }\end{array}$ & -- & $0.062 * *$ & 0.154 & 0.083 & 0.022 & -0.28 \\
\hline $\begin{array}{l}\text { Encouraging long-term } \\
\text { employment practice }\end{array}$ & 0.015 & -- & 0.229 & -0.019 & 0.004 & -0.189 \\
\hline $\begin{array}{l}\text { "Innovative" HRM } \\
\text { practices }\end{array}$ & 0.007 & $0.019 *$ & -- & $0.033 * * *$ & 0.001 & -0.035 \\
\hline $\begin{array}{l}\text { High workplace } \\
\text { training }\end{array}$ & $0.061 *$ & -0.028 & $2.14 * * *$ & -- & 0.033 & $3.35 * *$ \\
\hline Relative wage & 0.012 & -0.019 & -0.310 & 0.029 & -- & $14.37 * * *$ \\
\hline Av. working hrs & -0.001 & -0.001 & 0.015 & $0.005^{* *}$ & $0.025 * * *$ & -- \\
\hline $\begin{array}{l}\text { Proportion with higher } \\
\text { ed }\end{array}$ & $-0.087^{*}$ & -0.200 & 0.569 & $0.261 * * *$ & $0.321 * * *$ & $-5.59 * * *$ \\
\hline $\begin{array}{l}\text { Proportion with } \\
\text { secondary ed }\end{array}$ & 0.035 & -0.026 & $0.606^{*}$ & $0.124 * *$ & $0.090 *$ & $-2.87 * *$ \\
\hline Average worker tenure & 0.000 & -0.008 & -0.003 & 0.002 & -0.002 & -0.042 \\
\hline $\begin{array}{l}\text { Communication- } \\
\text { medium }\end{array}$ & 0.033 & $0.165^{* *}$ & $0.493 *$ & 0.009 & 0.024 & 0.515 \\
\hline $\begin{array}{l}\text { Communication-high } \\
\text { (Reference category - } \\
\text { low) }\end{array}$ & 0.043 & $0.210^{* *}$ & $1.515 * * *$ & $0.080 * *$ & 0.028 & 0.650 \\
\hline $\begin{array}{l}\text { Log of establishment } \\
\text { age }\end{array}$ & -0.006 & 0.027 & -0.099 & -0.002 & -0.013 & -0.043 \\
\hline $\begin{array}{l}\text { Log of establishment } \\
\text { size }\end{array}$ & -0.011 & 0.006 & $0.348 * * *$ & $-0.033 * * *$ & $0.029 * * *$ & 0.184 \\
\hline Foreign owned & 0.009 & $-0.114 *$ & 0.207 & -0.019 & 0.000 & $1.98^{*}$ \\
\hline Single establishment & 0.041 & -0.061 & $-0.772 * * *$ & -0.007 & -0.042 & $-1.13^{*}$ \\
\hline Union membership & $0.118 * * *$ & -0.062 & 0.419 & -0.045 & $0.106^{* *}$ & -0.628 \\
\hline $\begin{array}{l}\text { Market orientation - } \\
\text { UK }\end{array}$ & $-0.059 * *$ & 0.069 & -0.025 & $0.077 * *$ & $-0.065^{*}$ & -0.256 \\
\hline Degree of Competition & 0.015 & -0.011 & -0.103 & 0.012 & -0.019 & -0.225 \\
\hline $\mathrm{R}^{2}$ & NA & NA & 0.47 & 0.37 & 0.34 & 0.57 \\
\hline $\mathrm{N}$ & 1403 & 1403 & 1403 & 1403 & 1403 & 1403 \\
\hline
\end{tabular}

Notes: Sample excludes workplaces smaller than 5. Regressions include industry (12 dummies) and regional controls (9 dummies). 
(1) Guaranteed job security practice $=1$ if the workplace has a practice of guaranteed job security/no compulsory redundancies for all employees at the workplace;

(2) Encouraging long-term employment practice $=1$ if the manager strongly agrees that "employees are led to expect long-term employment in this organisation";

(3) "Innovative" HRM practice is the sum of the 13 practices enumerated in the Notes to Table $1 \mathrm{~b}$.

The negative coefficient for public sector workplace is because the equation controls for variable (4), high training practice, which also correlates strongly with public sector workplace

(4) High training practice is the proportion of the workforce receiving 2 or more days of training arranged or paid for by the employer over the past 12 months.

(5) Workplace relative wage is the average workplace wage relative to the average for the workplace's occupational composition and industry. It does not include the value of the employer-provided pension.

(6) Usual worker hours including overtime.

$* * *, * *, *$ signify $1 \%, 5 \%$, and $10 \%$ significance levels. Standard errors are adjusted for clustering by workplace. Establishment survey weights are used with strata and weight information supplied with the dataset.

\section{APPENDIX 2: CALCULATING DIRECT AND INDIRECT EFFECTS OF GOVERNANCE}

\section{Appendix Table 2: Schematic links between Ownership, HRM, Feelings and Performance}

(all links are coefficients from linear probability models and are relative to private sector nonfamily, 0 denotes insignificant coefficient)

\begin{tabular}{|l|c|c|c|}
\hline & FNM & FOM & Public \\
\hline Type and HRM (matrix P) & 0 & & \\
\hline Policy of guaranteed job security & 0.13 & 0.12 & $0.1 \dagger$ \\
\hline Policy for employees to expect long-term emp & -0.40 & 0 & 0 \\
\hline Innovative HRM indicator & 0 & -0.08 & 0.12 \\
\hline High training in workplace & -0.08 & 0 & 0 \\
\hline Workplace relative wages & 2 & 4.5 & -2.8 \\
\hline Workplace av. working hours & & & \\
\hline Type and Feelings (matrix F) & 0 & 0.08 & -0.08 \\
\hline Loyalty & 0.1 & 0.04 & 0 \\
\hline Job Security & & & \\
\hline Type and Performance (matrix A) & 0.23 & 0.18 & $\mathrm{NA}$ \\
\hline Financial & 0 & 0 & $+\dagger \dagger$ \\
\hline Productivity & 0 & 0.19 & $-\dagger \dagger$ \\
\hline Quality & & & \\
\hline
\end{tabular}

Sources: matrix $\mathbf{P}$ - Appendix Table 1, first 3 rows; matrix $\mathbf{F}$, Tables 2 a and $3 a$; matrix $\mathbf{A}$, Table $4 \mathrm{a} . \dagger$ the public sector 0.1 guaranteed job security effect is taken from the union coefficient given strong unionism; $\dagger \dagger$ positive (negative) public sector productivity (quality) is shown in Table 4b's marginal effects.

Matrix A gives the direct effects of type on performance, eg, significant effects of FNM and FOM on financial performance.

Matrix $\mathbf{F}$ gives the direct effects of type on feelings, eg, no effect on loyalty for FNM, but a significant effect for job security.

Matrix $\mathbf{P}$ gives the effect of type on HRM practices ( its elements are $\partial \mathbf{p} / \partial \mathbf{t}$ ), eg, FNM has a significant links with policy for employees long-term employment and hours (positive), and innovative HRM practices and relative wages (negative). 
Appendix Table 3: Schematic Links between HRM, Feelings and Performance

(0 denotes insignificant coefficient)

\begin{tabular}{|l|l|c|c|c|c|}
\hline & Feelings (matrix G) & \multicolumn{2}{l|}{ Performance (matrix C) } \\
\hline & Loyalty & $\begin{array}{l}\text { Job } \\
\text { Security }\end{array}$ & Financial & $\begin{array}{l}\text { Prod- } \\
\text { uctivity }\end{array}$ & Quality \\
\hline Policy of guaranteed job security & 0 & -0.02 & 0 & 0 & 0 \\
\hline Policy for employees long-term emp & 0 & 0.16 & 0.12 & 0.25 & 0.17 \\
\hline Innovative HRM indicator & 0 & 0 & 0.08 & 0.04 & 0 \\
\hline High training in workplace & 0.4 & 0.27 & 0 & 0 & 0 \\
\hline Workplace relative wages & 0.13 & 0 & 0.43 & 0.25 & 0 \\
\hline Workplace av. working hours & -0.004 & 0 & 0 & 0 & 0 \\
\hline
\end{tabular}

Feelings and performance (matrix B)

Job Security

0.25

0.18

Sources: matrix $\mathbf{G}$, Tables $2 \mathrm{a}$ and $3 \mathrm{a} ; \mathbf{C}$ and $\mathbf{B}$, Table $4 \mathrm{a}$.

Matrix $\mathbf{G}$ shows how HRM practices link to feelings, eg, high training has strong effects, workplace working hours generally weak effects.

C shows how performance links to HRM practices eg. policy for employees long-term employment is linked with all 3 measures - strangely, high training has no significant effect on any performance measure.

B shows feelings link with performance, eg, loyalty links strongly with quality but not other measures, and job security mainly with finance.

\section{Calculating indirect effects of governance type}

Governance type works not only directly (controlling for worker feelings and HRM practices as in Table 4a), but also through worker feelings, and HRM practices. There are three indirect effects:

1) type affects performance by affecting worker feelings (matrixes $\mathbf{F} \times \mathbf{B}$ ). $\mathbf{F}$ shows for example that FNM has no significant effect on loyalty, only job security $(0.1)$. We then see that job security (B) affects financial performance (0.25), and so the FNM type's job security advantage exerts an extra indirect effect on financial performance. The FOM type (see F) has significant advantages both for loyalty $(0.08)$ and job security $(0.04)$, which then help quality via the loyalty link in $\mathbf{B}(0.18)$, and finance via the job security link (0.25). Finally, we see that the public sector actually has a negative link with loyalty in matrix $\mathrm{F}(-0.08)$, which then goes on to negatively affect quality in the public sector via the loyalty link in $\mathbf{B}(0.18)$.

2) type affects performance via HRM practices (matrixes $\mathbf{P} \times \mathbf{C}$ ). Generally these effects are small, because many of the coefficients either in $\mathbf{P}$ or $\mathbf{C}$ are zero. An interesting example is the practice of high workplace working hours, which is strongly linked with FOM workplaces in $\mathbf{P}$ (coefficient 4.5 hours). However, working hours do not affect any of the 3 aspects of performance, as shown in $\mathbf{C}$ (coefficients all 0 ). The converse case is workplace relative wages, which $\mathbf{C}$ shows has strong effects on finance (0.43), but which $\mathbf{P}$ shows is only linked with the FNM type (-0.08), which in turn implies a negative impact for FNM financial performance.

The most important type effect working via HRM practice is the policy for employees' long-term employment. P shows this practice is taken up by both FNM and FOM types ( 0.13 and 0.12 respectively), but neither of the other types. This practice is also important for all measures of performance as shown by $\mathbf{C}$, which thus gives a path for indirect effects.

3) type also affects performance through HRM practices which affect worker feelings and then performance $(\mathbf{P} \times \mathbf{G} \times \mathbf{B})$. These effects are smallest because of the triple multiplication. The main effect here works through the policy in FOM and FNM types of long-term employment (P) which then helps feeling of job security $(\mathbf{G})$ and hence financial performance $(\mathbf{B})$. 